\title{
NO (EASY) WAY OUT: \\ "LIQUIDATING" STIPULATED DAMAGES \\ FOR CONTRACTOR DELAY IN \\ PUBLIC CONSTRUCTION CONTRACTS
}

\author{
SCOTT M. TYLER
}

\section{INTRODUCTION}

"Liquidated damages" refers to an amount that contracting parties, at the time of contracting, agree shall be payable as compensation im the event of a breach. ${ }^{1}$ Such damages are designed to alleviate uncertainty over the extent of the parties' potential liability without relying on the courts. ${ }^{2}$ In the construction industry, owners and contractors frequently attempt to apply liquidated damages to project delays, stipulating a payment by the contractor or withholding by the owner for each day after the scheduled completion date. ${ }^{3}$ Ideally, these provisions should provide a simple and expedient method by which contracting parties may achieve their goals under the contract-compensation for delay and timely completion of the project. ${ }^{4}$ Under the current state of the law, however, the provisions do not achieve their potential as effective dispute avoidance mechanisms because parties often turn to the courts to adjudicate validity of the provisions on a case-by-case

1. 22 AM. JUR. 2D Damages $\S 683$ (1988).

2. See Elliot Axelrod, A Pragmatic Scrutiny of Liquidated Damages, 19 LiNColN L. REV. 79, 79 (1991).

3. 5 Samuel Williston, a treatise on the law of Contracts $\S 785$ (3d ed. 1961).

4. Although compensation for delay is on the minds of owners in stipulating damages, most parties obviously would prefer that their projects be completed on time to avoid unnecessary difficulty: "The sole purpose of a completion assessment is to assure that the contract work will be done within the time specified, . . . to threaten the Contractor with sufficient monetary loss so that he will find it advantageous to apply sufficient men and equipment to the work to get it done on time." HARRY W. JONES ET AL. CASES AND MATERIALS ON CONTRACTS 700 (1965), quoted in Justin Sweet, Liquidated Damages in California, 60 CAL. L. REV. 84, 122 (1972). Unfortunately, the use of per diem delay damages to ensure performance has never been accepted wholeheartedly by the courts. See infra notes $90-92$ and accompanying text. 
basis. With no guarantee that their provisions will be enforced, parties may be confronted with the very uncertainty they hoped to avoid. The indiscriminate use of the term "liquidated damages" in reference to stipulated sums is, therefore, inaccurate; only in enforceable provisions are damages really "liquidated" by the agreement. $^{6}$

The fact that courts are generally willing, whenever asked, to take a "second look" at stipulated damages provisions clearly threatens the usefulness of such clauses. ${ }^{7}$ In construction contracts, for example, contractors have little incentive to comply with scheduled completion dates if they believe that contractual delay damages provisions may not be enforced. ${ }^{8}$ When owners retaliate through self-help by withholding payment, contractors may be encouraged to abandon their projects and pursue legal action. Even if such challenges are unsuccessful, the mere fact that they are mounted in the first place is indicative of the failures of the current law of liquidated damages. If parties are obligated to prove to a court that the damages they set in order to avoid litigation are enforceable, what has been gained? At the very least, reform that would add clarity to the review process is certainly necessary.

Some commentators have suggested across-the-board liquidated damages reform without differentiating among the various types and contexts of provisions," and there is much evidence to justify carrying the debate that far. ${ }^{10}$ It is also arguable, on the other hand, that any meaningful change is practically or politically impossible because the sheer variety of liquidated damages disputes defies clarification im the law. Yet public construction procurement truly is different, and reform in that context is not only imperative, but viable and justifiable. Public construction contracts arise

5. See infra Section II(B).

6. I have labored in this Note for consistency, generally applying the term "liquidated damages" to provisions that have been judicially enforced.

7. Jeffrey W. Sacks \& Robert M. Daniszewski, One View Too Many: Courts Take a "Second Look" at Liquidated Damages Provisions, BOSTON B.J., Mar. 1990, at 12.

8. See infra Section II(B).

9. Sacks and Daniszewski, for example, provide real estate examples, but in advocating reform do not specifically distinguish between public and private contracts; between real estate contracts and contracts for construction, goods, or other services; or between liquidated damages for failure to purchase property and liquidated damages for delay or for failure to carry out any other obligation. Sacks \& Daniszewski, supra note 7, at 15.

10. See infra Sections II(B), IV(A). 
under diverse and variable circumstances, ${ }^{11}$ but they all share several characteristics that set them apart from other contracts. Most significant is the potential for harm to the public if delays occur. While determining who is actually responsible for delay in a complex public building project can be difficult, ${ }^{12}$ it is clear that dawdhing costs government entities, and by extension taxpayers, billions of dollars annually. The recently publicized overruns at the Denver International Airport, for example, have reached nearly $\$ 2$ billion. ${ }^{13}$ With more than half of the average American's income being siphoned off by the government, ${ }^{14}$ such waste must be reduced.

This Note advocates the enactment of a comprehensive, uniform liquidated damages statute to be adopted in all jurisdictions ${ }^{15}$ and applied to the public construction industry. Such a

11. My use of the phrase "public construction contracts" is not intended to limit the scope of this Note to only contracts for what is traditionally defined as "construction," such as carpentry, masonry, or electrical work. The phrase is meant to apply to the wide range of procurements that may be related in some way to public works projects. See Appendix § 2(15).

12. J. Charles Sheak \& Timothy J. Korzun, Liquidated Damages and the Surety: Are They Defensible?, THE CONSTRUCTION LAW., Apr. 1989, at 19, 21.

13. Keith DuBay, Building Cost for Denver Int'l Airport Rises Again, BOND BUYER, Feb. 2, 1994, at 3 (reporting that costs rose from $\$ 1.1$ billion to nearly $\$ 3$ billion, and completion lagged well behind schedule). Examples of other delay-related overruns are ubiquitous. See, e.g., Douglas G. Smith, Delivering Public Works Projects-Different Approaches, PUB. WORKs, Mar. 1994, at 61 ("[M]ost public works owners . . . have dealt with cost overruns, schedule delays, ... and perhaps even a lawsuit."); see also Mark Arner, Port Commission Agrees to Pay $\$ I 7$ Million to Resolve Lawsuit over Convention Center Delays, SAN Diego Union-TRIB., Sept. 24, 1993, at C1 (noting cost of convention center of $\$ 100$ million more than expected and delay of one year); Bill Keveney, State Agency Taking Over DOT Project After Firing, HARTFORD COURANT, Apr. 17, 1993, at B5 (noting $\$ 9.9$ million increase in contract price because of delay); Robert Morris, Was City Misled over Construction Delays?, Bus. J.-CharlotTE, Feb. 21, 1994, § 1, at 2 (reporting that cost of convention center would be $\$ 2$ million more than expected and that it was still unclear when the project already three months behind schedule would be completed).

14. See Cost of Government Day Fact Sheet, Cost of Government DAY REPORT, (Americans for Tax Reform, Washington, D.C.), July 7, 1994.

15. To be most effective, the statute would need to be used in all of the remarkable variety of forums that hear public construction contract disputes, including state courts, state claims courts, federal district courts, the U.S. Court of Appeals for the Federal Circuit, the Court of Federal Claims, and all of the federal agency boards of contract appeals. The statute would be comparable to the Uniform Commercial Code (U.C.C.) as it applies to the states. In the realm of federal contracts, in which the boards and courts have developed what is essentially a federal common law, the statute would be equally important. 
statute would provide for a presumption of validity in certain clear factual situations and as a result truly would allow parties to "liquidate" stipulated damages for delay. Owners, contractors, and taxpayers would benefit because the statute would facilitate the efficient use of tax dollars and the timely completion of public contracts by providing contracting parties with positive and negative financial incentives. Part I of this Note demonstrates the problems faced by public owners when contractors seek "an easy way out" of their responsibility for delay, as well as the benefits to all parties when delay is avoided. Part II is an overview of the law of hquidated damages, from an historic perspective and as it exists today. Part III examines existing statutory attempts at providing standards of enforcement for liquidated damages. Part IV further explains why public construction procurement is unique and the need for reform is urgent; it also details a model statute, set forth in the Appendix, with the potential to resolve the delay-related uncertainty in public construction contracts.

\section{FAILURE, SUCCESS, AND Financial INCENTIVES}

The following scenarios demonstrate both the best and the worst possible outcomes of the use of financial incentives that include liquidated damages for delay. Scenario $A$ is based closely on an actual case ${ }^{16}$ and is representative of the problems that can result when a public owner decides to impose hiquidated damages for delay. As we shall see, judicial invalidation of such a contracted recovery can have disastrous effects-increased completion costs, delay damage, and legal fees-especially for small or lowincome municipalities. Scenario $B$, on the other hand, deals with a natural disaster and the rebuilding successes that can occur when parties take financial incentives seriously. On these occasions, ontime performance can lead to significant rewards for everyone involved.

In this Note the term "courts" is often used generically, for convenience, to refer to all forums that hear contract cases, including courts, as well as forums that might otherwise be called "boards."

16. See County of Del. v. J \& D Distrib. \& Mfg., Inc., 557 N.Y.S.2d 642 (App. Div. 1990). Detailed facts from the case were not published by the court, but suffice it to say that those included here are only slightly simplified. 


\section{A. Failure}

In the mid-1980s, the Board of Supervisors of a rural New York county concluded that area residents were inadequately served by the county's cramped government offices. The Board hired an architect, who in turn drew up specifications for a twostory county office building with a projected cost of $\$ 2.2$ million-a considerable sum to be taken from the region's public coffers. Pursuant to New York's Wicks Law, ${ }^{17}$ the county advertised for four separate bids, one each for the plumbing, electrical, mechanical, and general contracts. Included in the distributed general contract, a standard public construction document, was a provision for stipulated damages to be paid to the county in case of delay in the completion of the building. ${ }^{18}$ At the conclusion of the bidding process, a small contractor from an adjacent county was deemed the "lowest responsible bidder"19 for the general contractor slot. Once a surety was located to provide the necessary bonds, ${ }^{20}$ the Board executed the contract and finalized a construction schedule with the contractor. The schedule set November 15 , 1986 , as the completion date, allowing the contractor six full months to erect and enclose the building before the onset of win-

17. N.Y. GEN. MUN. LAW § 101 (McKinney 1986). The statute requires local governments to divide contracts into at least three subparts of work when the value of a building project exceeds $\$ 50,000$. Id. $\$ 101(1)$-(2).

18. The language of the clause was as follows:

LIQUIDATED DAMAGES: Time is of the essence in the completion of this project. As actual damages for any delay are impossible to determine, in the event the Contractor fails to complete the work in accordance with the time schedule, he and/or his sureties agree to pay the County liquidated damages in the sum of Four Hundred Dollars $(\$ 400)$ for each calendar day of delay in completing the work.

19. N.Y. GEN. MUN. LAW $\S 103(1)$ (McKinney 1986). All 50 states, as well as the federal government, have promulgated statutes that enunciate specific procedures for taking bids on public construction projects. These statutes generally require the government entity to award contracts to the "lowest responsible bidder." See, e.g., ALASKA STAT. \$ 36.30.170(a) (1992) (awarding to the "lowest responsible and responsive bidder"); MONT. CODE ANN. § 18-4-303(7) (1993) (awarding to the "lowest responsible and responsive bidder"); TENN. CODE ANN. \& 12-4-109(2) (1992) (stating that contracts must be awarded to vendor with "lowest responsible bid").

20. Payment and performance bonds are agreements between the owner and an insurance company (the "surety") that are procured by the contractor. "A performance bond obligates the surety to assume primary responsibility for completion of the contract if the original contractor is unable to complete it." Indemnity Ins. Co. v. United States, 14 Cl. Ct. 219, 221 n.1 (1988). A "payment bond" protects subcontractors, laborers, and material men by requiring the surety to pay them if the contractor fails to do so. Id. 
ter. Work began and proceeded without incident for most of the summer of 1986. The contractor submitted requisitions for progress payments every thirty days during this period, ${ }^{21}$ and the county quickly approved and paid the requested amounts.

The first delays occurred in late August. As soon as the second-floor steel was delivered, the contractor discovered that measurement errors had been committed at some point durmg the fabrication. Two trips back to the shop over the following weeks were necessary to correct the problem. Additional mistakes appeared in the steel beams for the roof, and the contractor began to realize that the distance from his office to the project site was more burdensome than expected. The November 15 completion date came and went, as did the first heavy snow on the unenclosed building. By late January 1987, the Board of Supervisors was utterly frustrated. The county had continued to make progress payments since November, albeit for much smaller amounts, and had even granted the contractor an official extension to January 1 , 1987. But the Board's repeated requests for the contractor to pick up the pace went unheeded.

On February 1 , the contractor submitted a payment requisition for $\$ 41,000$. The members of the Board saw only one option in response: recalling the stipulated damages provision in the contract, they remitted payment to the contractor on February 15 only after deducting $\$ 18,000$ to account for the forty-five days of delay after January $1 .^{22}$ Incensed, the contractor fulminated over what he saw as a material breach-the withholding of monies due-and ordered his men off the jobsite. Soon after the contractor's abandonment, the surety similarly denounced the assessment of stipulated damages and refused to uphold its customary obligations under the performance bond. ${ }^{23}$ The Board thus was forced to hire another general contractor on short notice and at high cost, to salvage the job. In the end, this simple office building cost

21. See N.Y. GEN. MUN. LAW § 106-b (McKinney 1986) (regarding procedure for progress payments in public contracts).

22. The Board first communicated its intent to do so via letter, to give the contractor a final opportunity to return to schedule.

23. Under a performance and completion bond, a surety generally has two options upon its principal's default: (1) the surety may undertake to complete the principal's work itself; or (2) the surety may pay the obligee its damages under the bond, essentially the obligee's cost of completion by hiring another contractor. See United States v. Seaboard Sur. Co., 817 F.2d 956, 959 (2d Cir.), cert. denied, 484 U.S. 855 (1987). A surety may also, of course, challenge the propriety of the termination. Id. 
the county $\$ 1.2$ million more than anticipated and was finished nearly a year behind schedule.

In an attempt to recoup some of its massive expenses, the county filed an action for $\$ 800,000^{24}$ against the contractor and the surety in New York Supreme Court. The contractor responded with a counterclaim for $\$ 168,000$ - his anticipated profits on the project plus the $\$ 18,000$ withheld for the delay. Six years passed before a date was set for trial, a rather common result in litigation over public construction contracts due to often complicated discovery. ${ }^{25}$ The trial judge, basing his decision on City of Elmira $v$. Larry Walter, Inc. ${ }^{26}$ held that liquidated damages could not accrue unless the contractor completed the project. He consequently found that the county's withholding of payment was unauthorized by the contract and constituted a material breach justifying the contractor's abandonment. The judge reserved only the question of damages for the members of the jury, and they returned a verdict in favor of the contractor for $\$ 150,000$.

As anyone involved im the construction industry realizes, significant delay in completing contracts-like that faced by the county-is surprisingly common. ${ }^{27}$ Faced with a delayed project, owners are required to make difficult decisions in a context of considerable uncertainty. On the one liand, an owner may believe that completion of the contract with the existing contractor will be more cost-efficient than terminating the contractor and hiring another. ${ }^{28}$ On the other hand, an owner working witlı a demonstrably unrehable contractor may have serious doubts about the contractor's ability to finish the contract witlin a reasonable time. In resolving this dilemma, soine owners choose to terminate, but many others decide to allow the contractor to continue working

24. Such amount represented the additional cost of completion for the general contracting work plus further damages for delay.

25. See Arner, supra note 13, at C1; Caty Van Housen, Solutions to Costly Disputes Being Sought, SAN DIEGo Bus. J., Aug. 23, 1993, at 1. Of course, legal fees accrued to the county throughout this period, eventually totaling more than $\$ 300,000$.

26. 564 N.E.2d 655,656 (N.Y. 1990) (ostensibly holding that liquidated damages provisions are inapplicable when the contractor abandons the project, unless such an eventuality is clearly and unambiguously contemplated by the language of the provision). Cf. infra text accompanying notes 153-59 (discussing further City of Elmira).

27. See, e.g., supra note 13 and accompanying text.

28. This would be a reasonable belief, especially with public contracts, because a replacement contractor is often secured on short notice and without fully competitive bidding. 
on the project. Either way, most owners would clearly prefer to avoid the decision and have their projects finished on schedule. They would even be willing, on most occasions, to pay a premium for the pleasure of timely or-dare they hope-early completion.

\section{B. Success}

Southern Californians were startled during the early morning hours of January 17, 1994, by a violent earthquake that would do much more than provide an unanticipated wake-up call. Although loss of life was relatively minimal given the strength of the quake, residents of the region soon faced a string of serious inconveniences. Many people suddenly found themselves injured, homeless, or out of a job. Not the least of these difficulties-because it affected almost everyone-was the widespread damage to the local freeway system, among the busiest in the world. The earthquake's violence caused lanes on previously stable ground to heave and crack, and rendered hundreds of bridges useless. Based on previous experience, ${ }^{29}$ most drivers envisioned a nightmare reconstruction that would lead to interninable gridlock, wasted resources, and flaring tempers. But the California Department of Transportation (Caltrans) was jolted by the January earthquake as much as everyone else, and administrators decided that where the freeways were concerned, they would try a different approach to repair. The results have been characterized by some commentators as "unbelievable." ${ }^{30}$

The first remarkable success came with the rebuilding of the bridges on the Santa Momica Freeway. To begin a story that is "short and sweet," the Federal Highway Administration (FHA) joined with Caltrans and put together a solicitation that contemplated a sixteen-week accelerated project schedule, many months shorter than the nornial expected construction time. ${ }^{31}$ After competitive bidding, the contract was awarded to local contractor Clinton Myers. The most important difference was the government's serious use of financial incentives, including a provision for liquidated damages of $\$ 200,000$ for every day of delay on the

29. Five years after the 1989 San Francisco earthquake, not a single damaged freeway there had been completely rebuilt. Ward E.Y. Elliott, Greenbacks Under Gridlock: The L.A. Freeway Solution. WASH. POST, Apr. 17. 1994, at C5.

30. Id.

31. See id. 
project. Rather than complain about the accelerated schedule and about such an obscene penalty, however, Myers got to work and focused on an obscene bonus-an extra $\$ 200,000$ per day for beating the deadlime. The contractor hired extra crews and equipment, worked around the clock, paid a lot of overtime, and finished the job ten weeks ahead of schedule. For his efforts, Myers made a killing; his reward amounted to more than $\$ 14$ million on what was originally a $\$ 15$ million contract. But the deal was even sweeter for the taxpayers of Southern California, who saved approximately $\$ 1$ million per day in transportation delay costs in exchange for the $\$ 200,000$ that was defrayed by the federal government. The total public savings, considering the already accelerated nature of the contract, was estimated at half a billion dollars. ${ }^{32}$

Caltrans quickly attempted to translate its success on the Santa Monica Freeway to other earthquake-repair projects, and transportation officials realized that the threat of liquidated daniages and the promise of bonuses had significant, tangible effects. ${ }^{33}$ Brutoco Engineering \& Construction, for example, ran into a problem while working on the eastbound lanes of the Simi Valley Freeway. According to one report, after reinforcing steel and concrete had been set im an excavation, mistakes were discovered in their placement. ${ }^{34}$ The steel had to be removed, adjusted, and replaced, but such events are relatively comnion at construction sites. Under normal circumstances, the project grinds to a halt, reports are filed, and disputes over fault break out. Thanks to financial incentives, however, "this was no normal job"35-Brutoco faced a $\$ 50,000$ per day liquidated damages provision for delays and a $\$ 50,000$ per day bonus provision for early completion. Consequently, "there were no disagreements, no lengthy discussions over who was to blame. The mistake was fixed immediately. ${ }^{\text {"36 }}$ As Brutoco executive vice president Tom Salata explained, "If you stand around arguing about reinforcing steel ... that's a $\$ 50,000$ conversation., ${ }^{37}$ The Simi Valley contract eventually was

32. See id.

33. See Judy Ronningen, Cypress Freeway to Reopen Early, S.F. CHRON., May 10, 1994, at A15.

34. Patrice Apodaca, Where It's Always Freeway Rush Hour, L.A. TIMES, May 17, 1994, Business Section, at 10.

35. Id.

36. Id.

37. Id. 
finished a few days early, netting Brutoco a six-figure reward. In another case, the north- and southbound lanes of the Golden State Freeway were opened by E.L. Yeager Construction Company, which completed two bridges one month early. The fast work earned the contractor a $\$ 4.5$ million bonus on top of its $\$ 14.8$ million payment for the contract. Finally, Kasler Corporation was encouraged to work quickly and efficiently by a $\$ 100,000$ per day bonus or penalty on a $\$ 19.6$ million contract to rebuild bridges on the Antelope Valley Freeway. ${ }^{38}$

The circumstances surrounding these California success stories were certainly exceptional and extreme. Caltrans was able to be so generous with bonus payments because the FHA provided fund$\mathrm{mg}$, and the tragedy of the earthquake probably greased the skids and allowed the government to contract in what would otherwise have been a politically questionable manner. ${ }^{39}$ It is also arguable that these scenarios, while testaments to the effectiveness of bonus payments, say hittle about the utility of liquidated damages for delay. The two contract tools sliould not be so easily distinguished, however, because they are designed to exert the same influence on contractors. Both liquidated damages and bonus payments are financial incentives, and as the earthquake-repair contracts clearly demonstrate, "[p]eople do respond to econonric incentives, often with huge advantages to everyone involved." pleted more quickly, and thus anything that boosts the credibility of financial imcentives will conserve resources in the future.

38. Id.

39. In fact, Caltrans came under fire soon after the Santa Monica project was completed. Some people apparently took issue with the government for threatening contractors with liquidated damages when their contracts already contained accelerated schedules. See $i d$. These critics refused to acknowledge that many contractors were willing to accept the risk of losses because of the concomitant potential for bonuses. A different group of people complained about the extremely generous nature of those bonuses. See id. They obviously saw only the tangible costs and not the tremendous public gains. As a result of this criticism, Caltrans eventually refused to offer early completion rewards to a contractor who had been selected to do additional work on the Simi Valley Freeway. The administrators did, however, continue to impose liquidated damages for delay. Henry Chu, Contractor Named for Simi Freeway Repairs, L.A. TiMES, May 13, 1994, at B9.

40. Elliott, supra note 29, at C5. 


\section{THE LAW OF LiQuidated Damages}

\section{A. History}

Historically, courts have exercised their enforcement authority in contract law by awarding damages; allowing parties to agree on their own damage award without judicial imtervention has been seen as allowing them to usurp the courts' authority. ${ }^{41}$ The development of the law of hquidated damages has culminated in a kimd of "mid-way approach"42 in this area, but stopping "mid-way" is often not an improveinent. If courts retain authority to consistently review stipulated damages, including those for delay in construction, then they have not conceded any meaningful powers to contractimg parties.

In early Enghish common law, people obligating themselves to one another through contracts continually sought to ensure performance or guarantee their recovery in case of breach. ${ }^{43}$ The use of penal bonds to achieve such goals was quite common. ${ }^{44}$ Under a penal bond, if the contractually required payment or performance was not rendered, the entire amount of the bond became due immediately regardless of the actual, provable damages suffered. ${ }^{45}$ To prevent this potentially oppressive result, the English courts of equity soon began to intercede at times on behalf of debtors by requiring them to pay only actual losses suffered by creditors. ${ }^{46}$ Therefore, what were in essence stipulated damages-the bonds-were eventually viewed with disfavor. Creditors were left with no choice but to forgo liquidation in favor of sumg at law for actual damages.

The generally negative English perspective on liquidated dainages carried over into early American legal opinions, which constricted it even further. Any attempt, no matter how reasonable, to assess damages without inquiry into their actual extent or char-

41. Marvin A. Chirelstein, Concepts and Case Analysis in the Law of CONTRACTS 169 (1990).

42. Id.

43. William K. Dix, The Use and Abuse of Liquidated Damages in Federal Defense Contracts: An Analysis, 8 OKLA. CITY U. L. REV. 251, 252-53 (1983).

44. See 5 ARTHUR L. CORBIN, CORBIN ON CONTRACTS $\S 1056$ (1950).

45. Id.

46. Axelrod, supra note 2 , at 80 . 
acter was held to be an unenforceable penalty. ${ }^{47}$ The concern for some courts, as in the case of penal bonds, was that unscrupulous parties would strive to collect excessive damages from inexperienced and foolish persons. Others worried that damages provisions would be used primarily to induce performance rather than to recover compensation for breach. ${ }^{48}$

American courts' initial aversion to liquidated damages far surpassed the level of disfavor in England, because the English recognized that there were imstances in which proving or coinputing actual damages was extremely difficult. In these circumstances they grudgingly accepted the concept of fixing damages in advance as a reasonable pre-estimate of actual damages. ${ }^{49}$ The "AngloSaxon reliance" on freedoin of contract and the importance of keeping one's word also had an impact on the English view. ${ }^{50}$ This eminently practical approach was not adopted in America until the mid-1800s, and then only sporadically. But United States courts increasingly gave credence to the justifications espoused in England and also acknowledged the time-saving impact of contracted dainages on increasingly crowded dockets. ${ }^{51}$ This judicial willimgness to accept such an apparent diminution of power was conditioned, however, on the continued rise of liquidated damages "rules" in inodern contract law.

The development of such rules was described in United States v. Bethlehem Steel Co. ${ }^{53}$ which is the paradigm Ainerican decision regarding liquidated damages provisions in all types of contracts. In Bethlehem Steel, the contract called for payinent by the contractor of thirty-five dollars per day for each day's delay in the delivery of gun carriages purchased by the government. The Supreme Court held this provision to be valid, despite the parties' desig-

47. See, e.g., Van Buren v. Digges, 52 U.S. (11 How.) 461, 476 (1850).

48. See 22 AM. JUR. 2D Damages § 693 (1988).

49. Axelrod, supra note 2, at 80-81.

50. Sides Constr. Co. v. City of Scott City, 581 S.W.2d 443, 447 (Mo. Ct. App. 1979) (summarizing history of liquidated damages).

51. RESTATEMENT (SECOND) OF CONTRACTS \& 356(1) cmt. a (1981). Compare Imperial Tobacco Co. v. Parslay, 2 All E.R. 515, 520-21 (C.A. 1936) (recounting judicial acceptance of valid liquidated damages provisions in England) with United States v. Bethlehem Steel Co., 205 U.S. 105 (1907) (discussed infra text accompanying notes 53-55).

52. Dix, supra note 43 , at 254 . For a complete exposition of the "rules," see infra Section II(B).

53. 205 U.S. at 105. 
nation of the payment as a penalty: $:^{54}$

The courts at one time seemed to be quite strong in their views and would scarcely admit that there ever was a valid contract providing for liquidated damages. Their tendency was to construe the language as a penalty, so that nothing but the actual damages sustained by the party aggrieved could be recovered. Subsequently the courts become more tolerant of such provisions, and have now become strongly inclined to allow parties to make their own contracts, and to carry out their intentions, even when it would result in the recovery of an amount stated as liquidated damages, upon proof of the violation of the contract, and without proof of the damages actually sustained. ... The question always is, what did the parties intend by the language used? ${ }^{55}$

Thus the Court professed to relax the established requirements for proof of damages and concentrated instead on the parties' intent.

Subsequent rulings in many jurisdictions further developed criteria to evaluate liquidated damages clauses. ${ }^{56}$ Yet these ruhings were not always completely consistent with the permissiveness of Bethlehem Steel.57 For example, the law for many courts evolved so that liquidated damages would be enforced only when they were reasonable estimates of the actual damages. ${ }^{58}$ The first $R e-$ statement of Contracts followed this result with the additional requirement that the expected damages be difficult to estimate. ${ }^{59}$ Also notable was that the Restatement and the contemporary caselaw mandated a presumption of invalidity that still lingers in

54. Id. at 120 .

55. Id. at 119 .

56. See infra Section II(B).

57. Contradictory rulings were issued even by the Supreme Court. See infra notes 91-92 and accompanying text. Compare, e.g., Robinson v. United States, 261 U.S. 486, 488 (1923) (allowing recovery of liquidated damages) with Priebe \& Sons v. United States, 332 U.S. 407, 413 (1947) (interpreting liquidated damages as a penalty).

58. See infra note 128. Such a rule seems to contradict the holding in Bethlehem Steel, which does not require proof of actual damages. See supra text accompanying note 55.

59. RESTATEMENT OF CONTRACTS $\S 339(1)$ (1932). This section provides:

An agreement, made in advance of breach, fixing the damages therefor, is not enforceable as a contract and does not affect the damages recoverable for the breach, unless

(a) the amount so fixed is a reasonable forecast of just compensation for the harm that is caused by the breach, and

(b) the harm that is caused by the breach is one that is incapable or very difficult of accurate estimation. 
some jurisdictions today, i.e., the party claiming damages must prove the existence of an enforceable hquidated damages clause in order to recover. ${ }^{60}$

\section{B. The Law Today}

American jurists have struggled to balance opposing ideals where liquidated damages are concerned. The development of common law principles regarding the enforceability of liquidated damages provisions "has been marked with ambivalence as a result of efforts to reconcile concepts of contract damages as purely compensatory, recognition of reasonable and freely bargained for . . . clauses, and the hoary rejection of any results smacking of penalty." Despite this confusion, the evolution of standards of review appears to have reached a stasis. Although courts today generally look on fixed damages with favor, the complex set of common law rules has been designed to prevent parties from "going too far" in punishing breaches. As discussed below, this protectiveness can utterly destroy the objectives of fixing damages for breach in advance.

The application of strict standards that may lead to the invalidation of liquidated damages in all types of contracts has been justified by various arguments, such as the following:

(1) the central objective behind the system of contract remedies is compensatory, not punitive;

(2) penalty clauses discourage efficient breach; ${ }^{63}$

(3) invalidating penalties compensates for unequal bargaining involved in some contract negotiations; ${ }^{64}$

60. See, e.g., J.L. Davis \& Assocs. v. Heidler, 622 A.2d 923, 928 (N.J. Super. Ct. App. Div. 1993). Thus, while the Bethlehem Steel Court did not look at stipulated damages with disfavor, it implicitly presumed them to be void because parties seeking such damages would have to show that they had the proper intent. See Bethlehem Steel, 205 U.S. at 119-20. The Restatement presumed invalidity because the party seeking damages was required to establish that the fixed amount was reasonable compared to actual damages and that the harm was difficult to estimate. See supra note 59.

61. Shapiro v. Grinspoon, 541 N.E.2d 359, 364 (Mass. App. Ct. 1989).

62. RESTATEMENT (SECOND) OF CONTRACTS \& 356(1) cmt. a (1981).

63. David Brizzee, Liquidated Damages and the Penalty Rule: A Reassessment, 1991 B.Y.U. L. REv. 1613, 1625. Richard Posner is notable for his support of the argument that efficient breach should be encouraged to promote overall economic efficiency in society. See RICHARd A. POSNER, ECONOMIC ANALYSIS OF LAW 116 (3d ed. 1986).

64. Brizzee, supra note 63 , at 1627-28. 
(4) invalidating penalties prevents breach-inducing activities;, and

(5) upholding stipulated dainages in some situations would be "inappropriate" because of extrinsic circumstances. ${ }^{66}$

While the rationale of the common law is admirable, inconsistencies in its application ${ }^{67}$ have created a system that provides contractors in all settings with perverse incentives to challenge even fairly and reasonably administered stipulated damages provisions. The system thus negates the benefits of agreed remedies, especially their ability to keep parties out of court, by imviting later judicial scrutiny.

A contractor in a construction contract certainly may be liable under a liquidated damages for delay clause in appropriate circumstances. But the mere fact that a contractor has failed to complete the project within the time allotted is not in itself a guarantee that liquidated damages will be upleeld, even if unilaterally assessed by the owner. There are many obstacles on the road to achieving contracted recovery.

The owner's first liurdle often is found in uncertain burden of proof requirements, in that it may be difficult to determine which party must persuade the court. This uncertainty is not limited to the construction context; a construction example is used merely for demonstration purposes. In one sense the initial burden is always on the owner, because the owner must establish the planned and actual completion dates of the project in order to determine the proper amount of damages. ${ }^{68}$ The more significant task, however, is to demonstrate that the per diem amount of damages sliould or sliould not be enforced. Many autliorities act as if the issue is well settled and presume stipulated damages to be invalid, ${ }^{69}$ requiring the owner to show that it has complied with all the historical

65. POSNER, supra note 63, at 116.

66. Such "extrinsic" circumstances typically occur in the construction industry but may also occur elsewhere. They include contractor abandonment, substantial completion claims, and alleged waiver by the owner. See infra subsections II(B)(2)-(6).

67. See infra note 83 and aceompanying text.

68. Michael R. Finke, The Burden of Proof in Government Contract Schedule Delay Claims, 22 PUB. CONT. L.J. 125, 137 (1992).

69. See, e.g., General Ins. Co. of America v. Commerce Hyatt House, 5 Cal. App. 3d 460, 472 (Ct. App. 1970); J.L. Davis \& Assocs. v. Heidler, 622 A.2d 923, 928 (N.J. Super. Ct. App. Div. 1993); Clifford La Tourelle, AGBCA No. 93-132-1, 94-1 B.C.A. (CCH) II 26,509, at 131,961 (Nov. 27, 1993). 
requirements for enforcement of such provisions. ${ }^{70}$ Once the owner has produced its evidence, the contractor may offer evidence that the requirements were, in fact, not satisfied. Other authorities seem just as confident in holding that the mitial burden regarding enforceability is on the contractor. ${ }^{71}$ The distinction between approaches is of paramount importance, because meeting the burden of proof in complex construction cases "is frequently difficult and sometimes impossible." ${ }^{\text {"2 }}$ Placing the burden on owners effectively forces them to go to court every time they seek to impose fixed damages and greatly reduces their chances of success there. Even when a court occasionally has placed the burden on contractors, any doubt as to whether such a rule will be universally applied encourages contractors to challenge the assessment of even legitimate stipulated sums. Either way, the usefulness of liquidated damages provisions is diminished.

Regardless of who offers the first evidence, stipulated damages that eventually do not satisfy a given jurisdiction's requirements are held to be an unenforceable penalty. The contractor's first defenses against an owner's claim in any contractual setting are thus always intrinsic-related to whether the provision is, by its nature, a penalty. After that, the law provides contractors in construction contracts with a wide range of defenses that are extrinsic-dependent on outside circumstances particular to the industry. Given the usual complexity of construction defaults, most cases mclude some facts that support the assertion of one or more of these theories. ${ }^{73}$ Once liquidated damages provisions are held unenforceable, owners in all contracts are forced to sue for actual damages, and that costly and difficult process is what they presumably wished, above all, to avoid.

70. "Historical requirements" may mean any or all of the various common law requirements. Thus a court may require the owner to establish that the stipulated amount is a reasonable forecast of likely damages or that the anticipated harm is difficult to ascertain, or both. These principles, and their evolution over time, are discernible in RESTATEMENT OF CONTRACTS $§ 339(1)$ (1932) and RESTATEMENT (SECOND) OF CONTRACTS § 356(1) (1981).

71. These courts presume stipulated damages to be valid. See, e.g., United States v. National Bond. \& Accident Ins. Co., 711 F.2d 131, 134 (9th Cir. 1983); Mega Constr. Co. v. United States, 29 Fed. Cl. 396, 502 (1993); Henry Angelo \& Co., ASBCA No. 43,346, 93-3 B.C.A. (CCH) II 26,131 at 129,897 (May 26. 1993); Finke, supra note 68, at 137.

72. Sheak \& Korzun, supra note 12, at 21.

73. Id. at 19. Sheak and Korzun discuss the use of defenses by a surety seeking to avoid liquidated damages, but the options they discuss are open to contractors as well. 
1. Penalty. The concept of "penalty" encompasses all of the intrinsic defenses to the assessment of liquidated damages and represents a culmination of American courts' efforts to reconcile the noncompensatory attributes of such clauses. Again, a "penalty" has been distinguished from "liquidated damages" because it is used not as a measure of compensation for breach, but rather to punish default and ensure performance of the contract. ${ }^{74}$ The difference is significant, simce if a contractor can construe a provision as a penalty, courts will find it void, whereas if the provision is for liquidated damages, it will be enforced "according to its terms."75 Under current standards, nearly every jurisdiction answers the question of whether a stipulated sum is for a penalty or liquidated damages through the application of some variation of the updated common law rules embodied in the Restatement (Second) of Contracts. ${ }^{76}$ The decision is a question of law dependent on the trier's construction of the contract.

Some courts translate the Restatement language into two conditions: a stipulated sum is for liquidated damages only when (1) the damages that the parties anticipate are "difficult to ascertain because of their indefiniteness or uncertainty"7 and (2) the amount stipulated is either "a reasonable estimate of the damages which would probably be caused by a breach or is reasonably proportionate to the damages which have actually been caused by the breach." ${ }^{78}$ Other authorities impose as an additional requirement that the parties must have intended, in fact, to liquidate the damages and not merely to impose a penalty. ${ }^{79}$ When intent is thus scrutinized, the parties' description of the stipulated sums as "liquidated damages," "penalt[ies]," or "forfeiture[s]" is considered,

74. 22 AM. JUR. 2D Damages $\S 684$ (1988).

75. Id.

76. RESTATEMENT (SECOND) OF CONTRACTS \& 356(1) (1981). This section provides:

Damages for breach by either party may be liquidated in the agreement but only at an amount that is reasonable in the light of the anticipated or actual loss caused by the breach and the difficulties of proof of loss. A term fixing unreasonably large liquidated damages is unenforceable on grounds of public policy as a penalty.

77. 22 AM. JUR. 2D Damages § 690 (1988). Compare RESTATEMENT (SECOND) OF CONTRACTS § 356(1) (1981) with RESTATEMENT OF CONTRACTS $§ 339(1)$ (1932).

78. 22 AM. JUR. 2D Damages $\$ 690$ (1988).

79. Dix, supra note 43 , at 255 . 
but is not controlling, in the determination of whether a contract provision is valid. ${ }^{80}$

Although the penalty rule as stated appears workable, in practice it suffers from several important interpretive problems. Most obvious is the question of how significant a role "intent" and "uncertainty" play. Confusion also arises from the ambiguity inherent in the terms "difficult" and "reasonable," as well as from the "either/or test" 82 that determines what is a reasonable stipulated sum. Not surprisingly, with every jurisdiction in the country free to interpret the Restatement provisions as it pleases, the result has been wildly unpredictable application of the law. ${ }^{83}$ All fifty states, as well as the federal government, have now fashioned statutes and regulations in respect to the use of liquidated damages in public construction contracts, pnblic and private construction contracts, or contracts in general. Some even require that government projects include such a clause. ${ }^{84}$ The vast majority of these mandates, however, either retain the uncertainty of the Restatement or fail to offer a test for vahidity at all. ${ }^{85} \mathrm{~A}$ scant few states have

80. 22 AM. JUR. 2D Damages $\S$ 694-697 (1988); see also United States v. Bethlehem Steel Co., 205 U.S. 105, 120 (1907); Kirkland Distrib. Co. v. United States, 276 F.2d 138, 144 (4th Cir. 1960); Annotation, Contractual Provision for Per Diem Payments for Delay in Performance as One for Liquidated Damages or Penalty, 12 A.L.R. 4TH 891, 900 (1982).

81. Brizzee, supra note 63 , at 1622 .

82. Axelrod, supra note 2, at 83. In other words, the Restatement requires that the amount of fixed damages be reasonable "in the light of the anticipated or actual loss caused by the breach." RESTATEMENT (SECOND) OF CONTRACTS § 356(1) (1981) (emphasis added); see infra notes 104-25 and accompanying text.

83. Brizzee, supra note 63 , at 1622 (arguing that "the tests used to distinguish the penalty from a valid liquidated damages provision are inconsistent and not uniformly applied").

84. See, e.g., FLA. STAT. ANN. $§ 337.18$ (West 1994).

85. See, e.g., ALASKA STAT. \& 36.30.430(b)(1) (1992) ("In state contracts, t]he commissioner shall adopt regulations permitting or requiring the inclusion ... of clauses providing for ... liquidated damages."); LA. REV. STAT. ANN. § 39:1661(B)(1) (West 1989) ("Regulations may permit or require the inclusion in state contracts of clauses providing for . . . liquidated damages as appropriate."); MD. CODE ANN. STATE FIN. \& PROC. § 13-218(a)(4) (Supp. 1993) ("[State procurement contracts] shall include clauses covering ... liquidated damages, as appropriate"); OHIO REV. CODE ANN. § 731.15 (Baldwin 1992) ("When a bonus is offered for completion of a contract prior to a specified date, [a village] may exact a prorated penalty in like sum for each day of delay beyond the specified date."); OKLA. STAT. ANN. tit. 15, §§ 214-215 (West 1993) ("A stipulation ... providing for the payment of an amount which shall be presumed to be an amount of damage sustained by a breach of such contract, shall be held valid, when, from the nature of the case, it would be impracticable or extremely difficult to fix the actual damage."); Acquisition Regulation, 48 C.F.R. $\$ 12.202$ (1993) (permitting liquidated 
gone so far as to adopt legislation that sets forth specific criteria under which fixed damages are presumed valid. Absent a controlling statute, courts generally determine validity in all types of contracts according to their interpretations of the Restatement doctrine. ${ }^{86}$

In light of the inherent unrehability of common law guidelines and the inefficacy of most relevant statutes, the penalty rule is by far the most prevalent defensive argument for avoiding an assessment of hquidated damages in all contracts, including construction contracts. ${ }^{87}$ Once a court decides the order in which the parties will deal with specific penalty rules-who bears the burden of proof $^{88}$-the focus shifts once more to the workings of those rules, such as the role of intent. The issue of intent of the parties as a basis for finding a penalty is problematic because of widespread confusion over the proper role of intent in the adjudication of validity. When intent is professedly considered, it is to discern the parties' true purpose in contracting for stipulated damages. ${ }^{89}$

The majority rule, evidenced recently in Rohlin Construction Co. v. City of Hinton, ${ }^{90}$ is that if the owner intends to deter a contractor from breaching, punish him for breaching, or provide security for actual damages, the clause is an unenforceable penalty. ${ }^{91}$ Other authorities, however, argue the opposite..$^{92}$ In Rohlin,

damages only "when ... the Government may reasonably expect to suffer damage if ... performance is delinquent, and ... the extent ... of such damage would be difficult or impossible to ascertain or prove.").

86. James A. Weisfield, Note, "Keep the Change!": A Critique of the No Actual Injury Defense to Liquidated Damages, 65 WASH. L. REV. 977, 980 (1990).

87. Sheak \& Korzun, supra note 12, at 20.

88. See supra notes $68-72$ and accompanying text.

89. See Kirkland Distrib. Co. v. United States, 276 F.2d 138, 144 (4th Cir. 1960).

90. 476 N.W.2d 78 (Iowa 1991).

91. See Priebe \& Sons, Inc. v. United States, 332 U.S. 407, 413 (1947) (arguing that "it is well settled contract law that courts do not give their imprimatur to stipulated damages that serve as an added spur to performance"); P \& D Contractors, Inc. v. United States, $25 \mathrm{Cl}$. Ct. 237, 240 (1992) (stating that stipulated damages are invalid when they serve as an "added spur to performance"); Melwood Constr. Corp. v. State, 481 N.Y.S.2d 289, 290 (Ct. Cl. 1984) (asserting that stipulated damages are "deemed punitive and unenforceable when [they serve] to secure a party's performance of the contract"), aff'd, 501 N.Y.S.2d 604 (App. Div. 1986); 5 CORBIN, supra note 44, § 1058.

92. See, e.g., Robinson v. United States, 261 U.S. 486, 488 (1923) (holding that stipulated damages "are an appropriate means of inducing due performance"); Ledbetter Bros., Inc. v. Department of Transp., 314 S.E.2d 761, $766-67$ (N.C. Ct. App. 1984) (finding that stipulated damages are the most effective way "to assure timely completion"); Reliance Ins. Co. v. Department of Transp., 858 P.2d 1363, 1370-71 (Utah 1993) (noting 
the plaintiff contractor sued to recover liquidated damages that had been withheld under three road construction contracts, one with Hinton, Iowa, and two with Plymouth County, Iowa. ${ }^{93}$ Each contract required that the work described therein be completed within forty "working days" and established $\$ 400$ per day as stipulated damages. The plaintiff finished 25.5 days late on the city contract and 27.5 days and 28 days late on the county contracts. Hinton responded by withholding $\$ 10,200$ from final payment as liquidated damages, while Plymouth County withheld $\$ 22,200$. The trial court ruled in favor of Rohlin, determining that the stipulated damages clauses in each contract were void as penalties. ${ }^{94}$ On appeal by the defendants, the Iowa Supreme Court, following the Restatement (Second) rule, questioned the process through which the per diem amount was derived. The court, while admitting that the defendants had suffered some harm, decided that there was not enough evidence to conclude that $\$ 400$ was the correct amount of daily compensation. ${ }^{95}$ As a result, the court affirmed because it assuined that the defendants' intent must have included the impermissible desire to ensure timely performance of the contract. ${ }^{96}$

Clearly, "intent" of the parties often must be ascertained through a "multi-factored analysis," especially in situations when there is no "meeting of the iminds" 98 in the ordinary sense to decide the issue-such as the competitively bid public projects in Rohlin. In those circumstances, when the contractor siniply agrees or disagrees with the particular amount of fixed daniages set by the owner, factors such as the nature of the contract, the amount of damages in relation to the total contract cost, and the situations of the parties become far more critical to a court determining validity by intent. ${ }^{99}$ Once these elements are considered, however,

that courts "have consistently held that liquidated damages... [are] an appropriate means of inducing timely performance"); 64 AM. JUR. 2D Public Works and Contracts \$ 127 (1988).

93. Rohlin, 476 N.W.2d at 79.

94. Id.

95. Id. at 81.

96. Id. The court reasoned that "the amount of liquidated damages set in each contract appears to be unreasonably large and goes far beyond the anticipated loss caused by delay in performance of the contract." Id. The court relied on the fact that the contracted amount was greater than the amount recommended by the state. Id.

97. Edward V. Crites, Liquidated Damages, J. Mo. B., Mar. 1991, at 98.

98. Sheak \& Korzun, supra note 12 , at 20.

99. Id. 
the court has begun a conscious or subconscious shift toward focusing on the "reasonableness" of the stipulated suin rather than on the parties' intent. The dividing line between the two standards is amorphous and once the court has ventured into the divide, the justifications for bothering to analyze "intent" quickly disappear. ${ }^{100}$ Agam, many authorities realize this fact and do not purport to consider the parties' intent. But continued uncertainty regarding the importance of the issue only exacerbates the confusion in the law.

The standard in those jurisdictions that have given up on intent and now concentrate on "reasonableness" is well established but flawed: a stipulated damage provision is unreasonable, and courts hold it to be an unenforceable penalty, if it is disproportionate to the harn actually sustained or likely to be sustained. ${ }^{101}$ The uncertainty of this standard lies in the subjectivity of interpretations of what is "grossly disproportionate,"102 as well as in the decision whether to judge a provision as of the time of contract formation or by the facts at the time of trial. ${ }^{103}$

A majority of jurisdictions consider whether an amount stipulated as liquidated damages bears a reasonable relation to the damages that reasonably might be expected to result from a breach. ${ }^{104}$ This approach contemplates a scrutiny of the circumstances known to the parties when setting the stipulated sum. ${ }^{105}$ Many shortsighted authorities also hold that "[i]t is impossible to lay down any abstract rule to deterinine if a pre-estimate of damages is unreasonable, for each case must, in great measure, depend on its own particular facts and circumstances."106 Admittedly, under the current state of the law some kind of case-by-case analysis is unavoidable. Yet to prohibit any abstract standard of reasonableness carries protectionism too far. As Rohlin and similar cas$e^{107}$ indicate, leaving the door open to judicial oversight regard-

100. See infra text accompanying notes 264-66.

101. RESTATEMENT (SECOND) OF CONTRACTS $\S 356(1)$ (1981); 22 AM. JuR. 2D Damages \$ 701 (1988).

102. 22 AM. JUR. 2D Damages § 701 (1988).

103. Remember that the Restatement promulgates an "either/or" test to determine what is a reasonable sum. See RESTATEMENT (SECOND) OF CONTRACTS $\$ 356(1)$ (1981).

104. Weisfield, supra note 86 , at 977.

105. P \& D Contractors, Inc. v. United States, $25 \mathrm{Cl}$. Ct. 237, 241, aff'd, 985 F.2d 583

(Fed. Cir. 1992); Mega Constr. Co. v. United States, 29 Fed. Cl. 396, 502 (1993).

106. 22 AM. Jü. 2D Damages § 703 (1988).

107. Space Master Int'I, Inc. v. City of Worcester, 940 F.2d 16, 20 (1st Cir. 1991) 
less of the circumstances can lead to dubious results. Contractors may be encouraged to file suit based on any deviation from the provable damages incurred by owners in similar cases as evidence that the damages assessed against them are invalid. ${ }^{103}$ The door is open even wider in the jurisdictions that follow the alternate test of the reasonableness of stipulated damages: whether the amount fixed "is reasonably proportionate or bears a rational relationship to the dainages that have actually been caused by the breach."109 Under this standard, the court considers the facts at time of trial. ${ }^{110}$ If it finds that no actual damages were caused by the breach, or that the stipulated damages are significantly greater than actual damages, the provision inay be held to be a penalty. ${ }^{111}$

Two conteinporary cases applying Massachusetts law, Shapiro v. Grinspoon ${ }^{112}$ and Colonial at Lynnfield, Inc. v. Sloan, ${ }^{113}$ are mdicative of the potential harm the "actual damages" test can inflict on the usefulness of liquidated damages provisions. ${ }^{114} \mathrm{~A}$ real estate transaction was the source of dispute in Shapiro. At issue was the seller's retention of the buyer's $\$ 500,000$ deposit as liquidated damages after the termination of the contract. ${ }^{115}$ The buyer's inortgagee had demanded a $\$ 625,000$ prepayment penalty, and although the seller offered to cover $\$ 425,000$ in order to close the sale, the buyer refused to continue. Four months after the scheduled closing date, the seller contracted witl a new buyer for $\$ 300,000$ more than he would have received from the first buy-

(forcing city whose classroom buildings were finished 200 days late to prove that its stipulated damages were reasonable and not in any way intended to punish breach, despite fact that classes had to be moved due to delay); Psaty \& Fuhrman, Inc. v. Housing Auth., 68 A.2d 32, 39 (R.I. 1949) (holding stipulated payment of only $\$ 25$ per day if landscaping work was not finished within 200 days not reasonable in view of the anticipated damages that would result from delay).

108. See, e.g., $P \& D$ Contractors, $25 \mathrm{Cl}$. Ct. at 240: Reliance Ins. Co. v. Department of Transp., 858 P.2d 1363, 1367-68 (Utah 1993).

109. 22 AM. JUR. 2D Damages $\S 704$ (1988) (emphasis added).

110. See, e.g., Lind Bldg. Corp. v. Pacific Bellevue Devs., 776 P.2d 977, 981 (Wash. Ct. App.), review denied, 781 P.2d 1322 (Wash. 1989); see also infra note 128 and accompanying text.

111. See Sacks \& Daniszewski, supra note 7, at 12 .

112. 541 N.E.2d 359 (Mass. App. Ct. 1989).

113. 870 F.2d 761 (1st Cir. 1989)

114. For additional insight into the impact of Shapiro, Colonial, and the actual damages test in general, see Sacks and Daniszewski's perceptive evaluation of Massachusetts law, supra note 7 , at 13-15.

115. Shapiro, 541 N.E.2d at 364. 
er. ${ }^{116}$ The trial court refused to consider the outcome of the later sale in determining the validity of the stipulated damages clause and ruled that, at the time of the contract execution, $\$ 500,000$ was a reasonable estimate of potential damages. ${ }^{117}$ Any further inquiry into events that occurred subsequent to the parties' entering into the agreement, according to the court, was equivalent to "Monday morning quarterbacking."

The appeals court disagreed with this "hands-off approach,"119 finding that Massachusetts law allowed for judicial review of the parties' fixed damages taking into account the actual damages incurred by the seller at the time of breach. ${ }^{120}$ As a result, the judgment was vacated and the case was remanded to determine the seller's actual damages and thus how inuch of the $\$ 500,000$ would have to be returned. ${ }^{121}$ Lost in the calculation, of course, were the legal fees incurred by the seller in pursuit of his defense.

Colonial at Lynnfield, Inc. v. Sloan ${ }^{122}$ dealt with two parties who had reached an impasse over the attempted sale of an interest in a troubled hotel. Like the trial court in Shapiro, the U.S. Court of Appeals for the First Circuit found that the stipulated damages agreed on by the parties represented a reasonable forecast of potential damages at the time the contract was executed. ${ }^{123}$ The court also posited, however, that it should evaluate a stipulated damages clause in light of events that were unknown to the parties when they entered the contract; in other words, a "retrospective appraisal" of actual damages was appropriate. ${ }^{124}$ From that vantage point, the seller's damages were determined to be something less than the amount of the stipulated damages, so the clause was held unenforceable. ${ }^{125}$ Once again the seller's goal of avoiding uncertainty and legal expenses was thwarted.

116. Id. at 363-64.

117. Id. at 364.

118. Id.

119. Sacks \& Daniszewski, supra note 7, at 13.

120. Shapiro, 541 N.E.2d at 364-66.

121. Id. at 366.

122. 870 F.2d 761 (1st Cir. 1989).

123. Id. at 765. The circuit court applied its interpretation of state law under the Erie doctrine. See Erie R.R. v. Tompkins, 304 U.S. 64, 78 (1938).

124. Colonial, 870 F.2d at 765.

125. Id. at $765-67$. 
Some observers certainly would hail decisions like Shapiro and Colonial as fair and well reasoned, and cases do exist in which the stipulated sum was clearly disproportionate. ${ }^{126}$ Unfortunately, viewed from another perspective, the "actual damages" test represents "a dismaying contribution," 127 which has been applied in several jurisdictions, ${ }^{128}$ to the erosion of the usefulness of liquidated damages. If the purpose of allowing parties to fix compensation in advance of breach is to enable them to understand at the time of entering the contract the risks to which they will be exposed and to conserve the resources of the judicial system, this test negates those benefits. Parties can avoid paying dainages-or at least believe they can-by marshalling any evidence that actual damages are less than those stipulated in the contract. ${ }^{129}$ This effect is problematic in all contractual contexts, including construction contracts.

The final problematic aspect of the penalty rule is in the application of the requirement of uncertainty regarding potential damages caused by a breach. The first Restatement of Contracts mandated that the resultant harm be "incapable or very difficult of accurate estimation" for a stipulated damages provision to be held valid. ${ }^{130}$ In the Restatement (Second), however, the standard is subtly different and has been subsumed into the concept of reasonableness. ${ }^{131}$ Courts must now contemplate an evidentiary problem: stipulated damages are enforced only if they are reasonable "in the light of the ... difficulties of proof of loss." ${ }^{\text {"132 }}$ In other

126. See, e.g., Phillips v. Phillips, 792 S.w.2d 269, $270-71$ (Tex. Ct. App. 1990) (declaring unenforceable liquidated damages provision of limited partnership agreement that stated that if general partner breached his trust thereunder he would be required to pay limited partner 10 times the amount she lost as a result of breach), aff'd, 820 S.W.2d 785 (Tex. 1992).

127. See Sacks \& Daniszewski, supra note 7, at 13.

128. See, e.g., Corrigan Co. Mechanical Contractors v. Fleischer, 423 S.W.2d 209, 214-15 (Mo. Ct. App. 1967); Willner v. Willner, 538 N.Y.S.2d 599, 603 (App. Div. 1989); Harty v. Bye, 483 P.2d 458, 463 (Or. 1971); Loggins Constr. Co. v. State Univ. Bd. of Regents, 543 S.W.2d 682, 685 (Tex. Civ. App. 1976).

129. Sacks \& Daniszewski, supra note 7, at 15; see also JEM Dev. Corp., ASBCA No. $45,912,94-1$ B.C.A. (CCH) II 26,407 , at 131,366 (Oct. 5, 1993) (holding against contractor who contended that liquidated damages should be returned because government might not have suffered any actual damages).

130. RESTATEMENT OF CONTRACTS $\S 339(1)$ (1932). The text of this section is provided in full supra note 59.

131. Restatement (SeCOND) OF ConTracts \& 356(1) (1981). The text of this section is provided in full supra note 76.

132. Id. 
words, the greater the difficulty of either proving that loss has occurred or establishing its amount with the requisite certainty, the easier it is to show that the amount fixed is reasonable. Only when the damages are difficult to determine do courts allow the parties to control the issue. This exception is justified by the fact that parties, particularly at the time of contract formation, are in as good a position as anyone to arrive at a fair measure of damages for a subsequent breach. ${ }^{133}$ Owner and contractor "are presumed to have taken the uncertain and speculative character of the damages into consideration when making the agreement, and to have agreed upon the definite sum for the purpose of putting the question of damages beyond controversy and dispute."134 These intentions are often foiled, however, because no bright line divides damages that comply with the rule from those that do not. ${ }^{135}$

In publicly bid contracts, especially those of the government, confusion arises over the issue of how inuch investigation is required before a harm may be considered impracticable to measure. Also uncertam is the significance of intangible damages to the public, such as general imconvemience, which often are not considered when "actual" damages are measured. Typically, the per diem amount is established by a form contract or by the owner through ad hoc means without an exhaustive attempt to predict or analyze the probable harm from delay. ${ }^{136}$ This process, even if undertaken in good faith, can result im the rejection of a claim for damages if the reviewing court finds that a different, practicable method existed for calculating the injury. ${ }^{137}$ When the stipulated sum de-

133. Solomon v. Department of State Highways \& Transp., 345 N.W.2d 717, 719-20 (Mich. Ct. App. 1984) (enforcing liquidated damages clause in construction contract, reasoning that otherwise it would be difficult to ascertain damages).

134. 22 AM. JUR. 2D Damages § 698 (1988).

135. Crites, supra note 97 , at 99.

136. Sheak \& Korzun, supra note 12, at 20. Other commentators have been even more frank about the process:

Whereas moderate liquidated damages such as $\$ 100$ per day may well be used to insure the completion of a normal project having no special urgency, higher amounts are used to force faster work on jobs which must be finished in less than a normal construction time. High assessments may be used to emphasize the need for haste and should be of sufficient size to make it economically desirable that the contractor expedite his work by use of multiple shifts or additional equipment.

Sweet, supra note 4, at 122 (citing JONES ET AL., supra note 4, at 700).

137. See Rice v. Schmid, 115 P.2d 498, 499-500 (Cal. 1941) (holding that flour involved in contract was "sold and offered for sale at quoted prices each day"); J. 
viates significantly from the owner's provable, monetary loss-when intangible damages to the public are anticipated, for example-such rejection is most common. ${ }^{138}$ Once again, these considerations have a negative impact on the law of liquidated damages, because contractors who can show an alternative measure of harm are provided with a basis to challenge even an appropriate assessment. ${ }^{139}$

2. Apportionment. The concept of apportionment is available to construction contractors as an extrinsic defense to the assessment of liquidated damages, but like the intrinsic penalty defense, it undermines the usefulness of liquidated damages provisions. When delays occur in a construction project, the facts are typically complex, and the cause of delay may be attributable to both the owner and the contractor, or to unforeseen circumstances. ${ }^{140} \mathrm{Au}-$ thorities are split on the impact such mixed responsibility should have on fixed dainages provisions. ${ }^{141}$ The legal principle is simple: "An owner cannot assess liquidated damages for delays in the contractor's performance which he has either caused or to which he has contributed." ${ }^{142}$ Most decisions indicate that courts are willing to apportion damages and apply the clause to that part of a delay for which the contractor is responsible, ${ }^{143}$ especially when the contract provides for apportionment. Unfortunately, some decisions indicate that mutual responsibility acts to abrogate a

Weinstein \& Sons, Inc. v. City of New York, 35 N.Y.S.2d 530, 532 (App. Div. 1942) (holding that fabric contracted for purchase had a readily ascertainable market value, was not unique, and was not something that could not be readily obtained elsewhere); Franchise Realty Interstate Corp. v. State College Shopping Ctr., Inc., 47 Pa. D. \& C.2d 632, 637-38 (1969) (holding that lost rental value of commercial space was easy to compute).

138. Sheak \& Korzun, supra note 12, at 21.

139. See id.

140. See id.

141. Compare sources cited infra note 143 with sources cited infra note 144 (demonstrating conflicting views on apportionment).

142. Sheak \& Korzun, supra note 12, at 21; see also United States v. Kanter, 137 F.2d 828, 830 (8th Cir. 1943).

143. See, e.g., Robinson v. United States, 261 U.S. 486, 488 (1923); Southwest Eng'g Co. v. United States, 341 F.2d 998, 1000 (8th Cir.), cert. denied, 382 U.S. 819 (1965); Tyger Constr. Co. v. United States, 31 Fed. Cl. 177, 259 (1994); City of Idaho Falls v. Beco Constr. Co., 850 P.2d 165, 170 (Idaho 1993); Calumet Constr. Corp. v. Metropolitan Sanitary Dist., 533 N.E.2d 453, 457 (Ill. App. Ct. 1988); see also infra text accompanying notes 290-97. 
liquidated damages clause altogether, ${ }^{144}$ regardless of express contractual terms to the contrary. ${ }^{145}$

These latter cases are represented by United States $v$. United Engineering \& Contracting Co. ${ }^{146}$ which generally is cited in support of the proposition that a court should not apply stipulated damages clauses when both parties have contributed to a delay. In the case, the plaintiff government claimed stipulated damages for delay in the completion of a construction contract, but the evidence indicated that much of the delay was caused by the plaintiff's own actions. ${ }^{147}$ The Supreme Court, in refusing to enforce the stipulated damages provision, reasoned,

We think the better rule is that when the contractor has agreed to do a piece of work within a given time and the parties have stipulated a fixed sum as liquidated damages not wholly disproportionate to the loss for each day's delay, in order to enforce such payment the other party must not prevent the performance of the contract withm the stipulated time, and that where such is the case, and thereafter the work is completed, though delayed by the fault of the contractor, the rule of the original contract cannot be insisted upon, and liquidated damages measured thereby are waived. ${ }^{148}$

While the contemporary approach is to apply liquidated damages provisions even when apportioning delay, United Engineering, although distinguished and limited by Robinson $v$. United States, ${ }^{149}$ has not been overturned. The resultant uncertainty regarding its significance can frustrate an owner's contractual attempts to protect itself if the contractor files suit.

Clearly, on many occasions contractors are justified in attacking stipulated damages, because the owner is responsible for some or all of the delay, or because the contractor has not assumed the risk of delay from unforeseen circumstances. On other occasions,

144. See, e.g., United States v. United Eng'g \& Contracting Co., 234 U.S. 236, 242 (1914); Youngdale \& Sons Constr. Co. v. United States, 27 Fed. Cl. 516, 564 (1993); Gaffny Corp., ASBCA Nos. 37,639, 39,740, 46,025-29, 94-1 B.C.A. (CCH) II 26,522, at 132,013 (Nov. 22, 1993); Coffey Constr. Co., VABCA Nos. 3361, 3432, 3473, 93-2 B.C.A. (CCH) II 25,788, at 128,325 (Feb. 11, 1993).

145. Caldwell \& Drake v. Schmalbach, 175 F. 429, 434 (4th Cir. 1909).

146. 234 U.S. at 236.

147. Id. at 239 .

148. Id. at 242 .

149. 261 U.S. 486 (1923); see infra text accompanying notes 290-97. 
however, uncertainty in the law gives a contractor who is at least partially at fault an incentive to challenge assessed damages in the hope that the per diem amount will be totally voided by a noapportionment rule. Even when contractors are completely responsible for a delay, they have nothing to lose-and very much to gain-by going to court and producing evidence that might give the appearance of some fault by the owners. ${ }^{150}$ Such results may occur even in jurisdictions that have permitted apportionment, because the law is often less than conclusive and may be open to attack. Often, therefore, the resource-saving objectives of fixing damages in advance can be thwarted.

3. Abandonment. The concept of abandonment is also available to construction contractors as an extrinsic defense to the assessment of hquidated damages and can undermine the usefulness of such provisions. When a contractor abandons work under a construction contract either before or after the scheduled completion date, the takeover by a surety or search to find a replacement contractor ${ }^{151}$ nearly always results $\dot{m}$ delay in the completion of the project. Since the first contractor is responsible, in a sense, for such delay, the question arises regarding his or his surety's responsibility for payment under a stipulated damages provision. ${ }^{152}$ Cases in which an owner attempts to enforce a fixed per diem sum against a contractor who has abandoned before the scheduled completion date are rare, but City of Elmira v. Larry Walter, Inc. ${ }^{153}$ appears to be representative. ${ }^{154}$ In that case, the parties

150. See, e.g., P.T. \& L. Constr. Co. v. State, 578 N.Y.S.2d 921, 922 (App. Div. 1992); G. Bliudzius Contractors, Inc., ASBCA Nos. 42,366, 42,368-70, 93-3 B.C.A. (CCH) q 26,074, at 129,592 (May 18, 1993). In Bliudzils, the Armed Services Board of Contract Appeals noted that "[a]ppellant has presented little more than an array of war stories complaining about the Government's delay to the project. ... We cannot simply presume that since there was a Government caused delay, that it follows that completion of the project was delayed." Id. at 129,592-93.

151. A replacement would be needed if the surety refused to engage in a takeover. See supra note 23 and accompanying text.

152. When a performance bond surety takes over a contract, it generally accepts all of the abandoning contractor's responsibilities-including the payment of liquidated damages. See Sheak \& Korzun, supra note 12, at 19. Cf. supra note 23 (describing other obligations of surety after takeover).

153. 564 N.E.2d 655 (N.Y. 1990).

154. See Sinnott v. Schumacher, 187 P. 105 (Cal. Ct. App. 1919); Murphy v. United States Fidelity \& Guar. Co., 91 N.Y.S. 582 (App. Div. 1905), aff'd, 76 N.E. 1101 (N.Y. 1906). But see Construction Contracting \& Management, Inc. v. McConnell, 815 P.2d 1161 
executed a contract for the construction of a municipal parking garage that included a provision for stipulated damages in case of delay. ${ }^{155}$ While construction on the project was underway, disputes arose over a number of issues and culminated in the contractor's abandonment of the project approximately five months before the contractually designated completion date. ${ }^{156}$ The city sued for breach after the project was completed late and was granted both actual and liquidated damages by the trial court. ${ }^{157}$ In affirming the appellate court's modification of the judgment to exclude the liquidated damages, the New York Court of Appeals held that " $[t]$ he only reasonable interpretation which can be given to [the liquidated damage] provision is ... that the liability for the stipulated sum did not accrue until the contractor had fulfilled [its] agreement by completing the project."158 The court stated that it would make an exception for those liquidated damages provisions that contain "clear and unambiguous language ... indicating that [the clause] was also intended to apply to defendant's outright abandonment." 159

Authorities are "irreconcilably split"160 in regard to those situations involving an abandonment after the scheduled completion date-when some delay has already occurred. Applying City of Elmira is not out of the question. Moreover, other courts have reached the same result: abandonment either before or after the scheduled completion date is not implicitly within the contemplation of a stipulated damages provision. ${ }^{161}$ These outcomes must

(N.M. 1991) (disagreeing with City of Elmira result).

155. City of Elmira, 564 N.E.2d at 656 . The agreement provided:

As actual damages for any delay in completing the work ... are impossible to determine, the Contractors and their Sureties shall be liable for . . . the sum of One Thousand Dollars $[(\$ 1000)] \ldots$ as fixed, agreed and liquidated damages for each calendar day of delay from the above stipulated completion . . . until Id. such work is satisfactorily completed and accepted.

156. Id. at 655 .

157. Id. Although the recovery of liquidated damages for delay precludes recovery of actual damages for delay, it generally does not preclude the awarding of actual damages for increased completion cost, since delay and completion cost are separate and distinct elements of the injury. See 5 CORBIN, supra note 44, § 1072.

158. City of Elmira, 564 N.E.2d at 656 (alterations in original) (quoting Murphy, 91 N.Y.S. at 585).

159. Id.

160. R.D. Hurs, Annotation, Liability of Building or Construction Contractor for Liquidated Damages for Breach of Time Limit Provision Where He Abandons Work After the Time Fixed for Its Completion, 42 A.L.R. 2D 1134, 1135 (1955).

161. Sce, e.g., Six Cos. v. Joint Highway Dist., 311 U.S. 180, 187 (1940). In this case, 
be contrasted with those in a majority of jurisdictions where courts have held fixed damages fully applicable to abandoning contractors who repudiate after the scheduled completion date. ${ }^{162}$ This "judicial disharmony"163 is compounded by the inability of the courts to agree on the appropriate period between abandonment and completion to which the liquidated damages provision should apply. ${ }^{164}$

All told, the uncertainty in this area of the law reveals that the issue of abandonment has significant potential to undercut the goals of stipulated damages in construction contracts, especially when the owner resorts to self-help assessment. A breaching contractor nuay be able to avoid the iniposition of otherwise valid per diem anounts simply by abandoning the contract, regardless of how much delay has occurred. Although the court in City of Elmira attempted to downplay this possibility, ${ }^{165}$ coninion sense indicates that the threat is real. The key language in City of Elmira and sinilar cases is that "liability for the stipulated sum [does] not accrue until the contractor [fulfills] his agreement."166 If consistently applied, this rule, as Scenario $A$ in Part I confirms, effectively may render any withholding of damages for delay an actionable breảch.

4. Substantial Completion. Substantial completion is another doctrine available to construction contractors as an extrinsic defense to the assessnient of liquidated damages and can undermine the usefulness of such provisions. Although there is authority to the contrary, ${ }^{167}$ as a general rule courts hold that substantial com-

the federal district court and court of appeals held that the provision was applicable and discredited a California case containing contrary statements. Id. at 184-85. The Supreme Court, reversing the decision below, held that under Erie the federal courts were bound by the California decision. Id. at 188; see also Canton v. Globe Indem. Co., 195 N.Y.S. 445 (App. Div. 1922) (holding liquidated damages inapplicable after abandonment).

162. See, e.g., Southern Pac. Co. v. Globe Indem. Co., 21 F.2d 288, 291 (2d Cir. 1927) (applying New York law); City of Boston v. New England Sales \& Mfg. Corp., 438 N.E.2d 68, 68 (Mass. 1982); Construction Contracting \& Management, Inc. v. McConnell, 815 P.2d 1161, 1167-68 (N.M. 1991); Austin-Griffith, Inc. v. Goldberg, 79 S.E.2d 447 (S.C. 1953).

163. Hurs, supra note 160 , at 1135 .

164. Id.

165. City of Elmira v. Larry Walter, Inc., 564 N.E.2d 655, 656 (N.Y. 1990).

166. Id.

167. E.g., Ledbetter Bros., Inc. v. Department of Transp., 314 S.E.2d 761, 766 (N.C. Ct. App. 1984); see also Reliance Ins. Co. v. Department of Transp., 858 P.2d 1363, 1370 
pletion of a project tolls the assessment of liquidated damages, ${ }^{168}$ inconsistent contract provisions notwithstanding. ${ }^{169}$ Whether a project is "substantially complete" on or before the scheduled completion date is a question of fact, ${ }^{170}$ and the standard is often held to have been reached when the work "is satisfactorily completed to the extent that facilities may be occupied or are actually used for the purpose for which they are intended."171 The period after that point, when only minor tasks remain, is often referred to as the "punch list" stage, ${ }^{172}$ stipulated damages assessed during that stage will be construed as a penalty. ${ }^{173}$

Although the doctrine appears reasonable, it is problematic for two reasons. First, in many situations parties find it difficult to determine exactly when substantial completion has taken place and what qualifies as a "punch list" item. ${ }^{174}$ The date of occupation is not controlling, because the standard is intended to be objective, and owners' views on the proper time to enter a facility may differ. ${ }^{175}$ Courts have been unable to delimeate a bright-line rule. In Thermodyn Contractors, Inc. v. General Services Administration, ${ }^{176}$ for example, Therınodyn challenged a government assessment of $\$ 22,630$ in liquidated damages for failure to complete improvements to a Texas border station on time. The contractor asserted that the project was substantially complete before April 23, 1993,

(Utah 1993).

168. Mount Olivet Baptist Church, Inc. v. Mid-State Builders, No. 84AP-363, 1985 WL 10493, at *6 (Ohio Ct. App. Oct. 31, 1985) (holding that substantial performance is "the event terminating [the contractor's] liability for liquidated damages"); S.L. Rowland Constr. Co. v. Beall Pipe \& Tank Corp., 540 P.2d 912, 921-22 (Wash. Ct. App. 1975); Gaffny Corp., ASBCA Nos. 37,639, 39,740, 46,025-29, 94-1 B.C.A. (CCH) \26,522, at 132,010-11 (Nov. 22, 1993).

169. See infra note 180 .

170. Seaboard Sur. Co., ASBCA No. $43,281,93-1$ B.C.A. (CCH) If 25,510 , at 127,045 (Oct. 20, 1992).

171. Sheak \& Korzun, supra note 12, at 23 (emphasis omitted); see also United States ex rel. Control Sys., Inc. v. Arundel Corp., 814 F.2d 193, 196 (5th Cir. 1987) (explaining that despite delays incurred in installing an electronic control system, project could be "functionally operational"-i.e., substantially complete-without it).

172. See, e.g., Gaffny Corp., ASBCA Nos. 37,369, 39,740, 46,025-29, 94-1 B.C.A. $(\mathrm{CCH})$ at 132,010 .

173. Sheak \& Korzun, supra note 12 , at 23.

174. Id.

175. See id.

176. GSBCA No. 12,510, 94-3 B.C.A. (CCH) If 27,071, 1994 WL 377727 (July 8, 1994). 
the date it was approved by the government. ${ }^{177}$ March 31 was a more appropriate determination of the date of substantial completion, argued Thermodyn, because that was when the owner occupied the border station and the work was "more than 99 percent complete" $" 178$ at that time.

The board of contract appeals, after endorsing the rule that substantial completion is determined by whether the facility in question is "occupied and used by the Government for the purposes for which it was intended,"179 held against Thermodyn and affirmed the assessment of liquidated damages until April 23..$^{180}$ The contractor had neglected to finish the security systems on the project, an item essential to the operation of a law enforcement facility like a border station. ${ }^{181}$ Ironically, however, the board did not take issue with Thermodyn's contention that the job was essentially finished. Yet the building was not being used as it was intended to be used-as a fully functioning border station. Thus the ambiguity mherent in the subjective phrase "substantial completion" is laid bare; what is substantial for one party obviously is not always substantial for the other. Due to this confusion, contractors have an incentive, as seen in Thermodyn, to challenge an otherwise valid liquidated damages provision if they believe that their project has a chance of being construed as "substantially complete." 182

The second problematic aspect of the doctrine of substantial completion relates to the parties' intentions in fixing damages and

177. Thermodyn, 1994 WL 377727 , at $* 1$.

178. Id. at $* 8$ (citations omitted).

179. Id.

180. April 23 was held to be the date of substantial completion. Id. at $* 11$. The board never even considered allowing stipulated damages to be applied after that point, despite the following language in the parties' contract: "If the Contractor fails to complete the work within the time specified in the contract ... the Contractor shall pay to the Government as liquidated damages, the sum of $\$ 730.00$ dollars for each day of delay." Id. (emphasis added). Thus the board applied the judicial rule that "complete" means "substantially complete" unless the contract explicitly says otherwise. $C f$., Reliance Ins. Co. v. Department of Transp., 858 P.2d 1363, 1370 (Utah 1993). The court in Reliance concluded that the doctrine of substantial completion did not apply because the contract set the completion date as "the date on which all work on the project shall be completed." Id. at 1365 . These cases indicate that under the current state of the law, parties cannot rely on the traditional definition of "complete"; they must take the additional step of defining it for themselves.

181. Thermodyn, $1994 \mathrm{WL} 377727$, at $* 10$.

182. See, e.g., id. at *9; J.W. Creech, Inc., ASBCA Nos. 45,317, 45,454, 94-1 B.C.A. (CCH) I 26,459, at 131,662 (Oct. 26, 1993); Reliance Ins., 858 P.2d at 1370. 
calls into question the logic underlying the doctrine itself. The issues are demonstrated effectively in S.L. Rowland Construction Co. v. Beall Pipe \& Tank Corp. ${ }^{183}$ in which a contractor (Rowland) and its surety brought an action against the city of Everett, Washington. The city, facing a "badly deteriorated" 22mile-long wooden pipeline from its water source, lad issued a solicitation for the construction of a new steel pipeline. Rowland was the low bidder, and the company agreed as part of the $\$ 2.4$ million deal to be liable for $\$ 150$ "for each day the job ran past the designated coinpletion date." 184 After only a portion of the line was in place, Rowland abandoned the job and left it to the surety to arrange for completion. The entire segment covered by the contract eventually was finished, but was nearly a year behind scliedule. ${ }^{185}$

At trial, Rowland and the surety blamed the city for their problems with the project and questioned the city's assessment of stipulated delay damages after what they believed was substantial coinpletion. The parties agreed that "the pipeline itself" was completed and operating on February 1, 1968, but the entire contract was not performed and accepted until June 18, $1968 .{ }^{186}$ During the four-and-a-half-month interim, the surety was performing, albeit slowly, punch list items "involving cleanup and landscaping." 187 After hearing the facts, the trial judge instructed the jury that it could not assess liquidated damages after the pipeline had been placed in service but before the project was complete. ${ }^{188}$ The resultant verdict "found for the City on all of the major issues" but still entered a judgment in favor of Rowland for $\$ 12,450{ }^{189}$ Both sides appealed.

The relevant issue for the court of appeals was whether the trial court erred by instructing the jury to follow the doctrine of substantial completion. The city claimed that the damages were necessary because it was still suffering harn during the period

183. 540 P.2d 912 (Wash. Ct. App. 1975).

184. Id. at 915 .

185. Id. at 914 .

186. Id. at $921-22$.

187. Id.

188. Id. at 921. Apparently, the judge believed that a factual determination regarding the exact date of substantial completion was unuecessary because the date of service provided an easily recognizable benchmark.

189. Id. at 915. 
after substantial completion; Rowland, on the other hand, insisted that the city's damages were minimal and that additional recovery by the city would amount to a penalty. ${ }^{190}$ Basing its decision on abundant precedent, the court acknowledged the city's loss but affirmed the judgment. During the punch list stage, the court contended, charging additional damages at the same per diem rate would betray the permissible purposes of contracted recovery. ${ }^{191}$ Because the harm inflicted on the city by an incomplete project was, presumably, much diminished after substantial completion, the effect of constant stipulated damages would be to induce performance, not to compensate for loss. Moreover, there was no longer "any real difficulty in ascertaining the damages that would be caused by such breaches once that point in the work was reached." 192

As Rowland indicates, ambiguity regarding what is "substantial" can be compounded by the questions that permeate the penalty defense as to what is a permissible "intent," what is "reasonable," and what is "difficult" to measure. Therefore, even when the date of substantial completion is not debatable-as in Rowland-the contractor may still have incentives to challenge an otherwise valid assessment of fixed damages by interposing penalty issues. Consequently, the usefulness of stipulating damages for delay is eroded once again. Seemingly forgotten by the authorities is the dual dilemma faced by the owner: (1) the harms caused by delay after substantial completion may be reduced, but they are not eliminated, and (2) the punch list stage may be the period when the contractor needs the most "encouragement" to get the job done.

5. Waiver. The concept of waiver constitutes another extrinsic defense to the assessment of liquidated damages in construction contracts. Breaching contractors often find that complex construction cases are conducive to the argument that the owner has either waived the contract completion date or waived its right to any fixed damages. ${ }^{193}$ "Common sense," according to some observers,

190. See id. at $920-21$.

191. Id. at $921-22$.

192. Id. at 922 .

193. Sheak \& Korzun, supra note 12, at 24; see also Bradford Elec. Co., ASBCA No. 43,356, 1994 WL 283726 (April 29, 1993) (involving claim by appellant that government waived liquidated damages because it failed to reserve its right to them in a contract 
forms the basis for the application of waiver as a defense, because "[e]ither at law or in equity, a stipulation regarding time, though otherwise of the essence, may be waived." ${ }^{194}$ When waiver is applied under current standards, it need not be express, but may be inferred from the conduct of the owner: ${ }^{195}$

When a specific time is fixed for the performance of a contract and is of the essence of the contract and it is not performed by that time, but the parties proceed with the performance of it after that time, the right to suddenly insist upon a forfeiture for failure to perform within the specified time will be deemed to have been waived and the time for performance will be deemed to have been extended for a reasonable time. ${ }^{196}$

Contractors find their best opportunity to claim the defense when the owner explicitly agrees to waive damages, ${ }^{197}$ fails to claim a stipulated sum until final payment, ${ }^{198}$ or directs or orders extra work after the scheduled completion date. ${ }^{199}$ Other situations, however, have warranted the application of the waiver doctrine as well, including cases in which the owner failed to give adequate notice before withholding danıages, ${ }^{200}$ failed to place the contractor in default, ${ }^{201}$ or neither mentioned nor assessed liquidated sunis for a period after the scheduled coinpletion date had passed. ${ }^{202}$ Of course, by giving the contractor a "second

modification).

194. Sheak \& Korzun, supra note 12, at 24 (quoting 6 Wiliston, supra note 3, $\S 856$ (3d ed. 1961)).

195. Id.

196. 6 WiLliston, supra note $3, \S 856$; see also Clifford La Tourelle, AGBCA 93-132-1, 94-1 B.C.A. (CCH) I 26,509 , at 131,962 (Nov. 22, 1993).

197. Sheak \& Korzun, supra note 12 , at 24.

198. Maryland Steel Co. v. United States, 235 U.S. 451, $455-56$ (1915); United States v. John Kerns Constr. Co., 140 F.2d 792, 793 (8th Cir. 1944); Alpine Constr. Co. v. Water Works Bd., 377 So. 2d 954, 955 (Ala. 1979).

199. Universal Builders, Inc. v. Moon Motor Lodge, Inc., 244 A.2d 10, 16 (Pa. 1968) (inferring that defendant owner had waived the requirement because its agent both requested extra work and watched the work being done); see also J.A. Jones Constr. Co. v. Greenbriar Shopping Ctr., 332 F. Supp. 1336, 1347-48 (N.D. Ga. 1971) (holding that voluntary payment estops reliance on the language of the contract), aff'd, 461 F.2d 1269 (5th Cir. 1972); Rockwell v. Mountain View Elec. Ass'n, 521 P.2d 1272, 1274 (Colo. 1974) (holding that executing change orders after contract completion date constitutes waiver).

200. Arctic Contractors, Inc. v. State, 564 P.2d 30, 43-44 (Alaska 1977).

201. See O \& M Constr., Inc. v. Division of Admin., 576 So. 2d 1030, 1037 (La. Ct. App. 1991).

202. Corway, Inc., ASBCA No. 20,683 , $77-1$ B.C.A. (CCH) II 12,357, at 59,804 (Feb. 
chance" in these ways, the owner's true intent actually may be to forgo damages. Furthermore, some of the actions are held not to constitute an implied waiver in a few jurisdictions. ${ }^{203}$ Yet contractors never are required to obtain explicit evidence of waiver from owners. It is possible, therefore, for contractors to enjoy the "windfall" that waiver often represents even when the owners did not intend to waive their rights. Such outcomes may encourage contractors to challenge liquidated damages provisions when owners merely stay their hands in good faith by not withholding damages.

6. Payment Due. The final primary extrinsic defense against the validity of stipulated damages provisions in construction contracts is also the least direct attack, and it applies only if the owner pursues self-help by withholding payment to the contractor. Because most jurisdictions understandably hold fast to the rule that failure to remit progress payments "due and owing" constitutes a material breach, owners are often forced into shouldering a heavy burden to prove that their unilateral assessment of damages was reasonable-especially in the absence of express contractual authority. The relevant standard is eminently rational and was designed to prevent, in essence, unjust enrichment:

[W] here the failure to pay an installment as provided in a construction contract is such a substantial breach that it materially impairs the contractor's ability to perform, he has the right to consider the contract at an end, to cease work, and to recover the value of the work already performed. ${ }^{204}$

Courts are willing to allow owners to withhold a certain set percentage $e^{205}$ of each progress payment, to be remitted when the

8, 1977); see also DeVito v. United States, 413 F.2d 1147, 1153 (Ct. Cl. 1969) (forfeiting right to terminate the contract); Sun Cal, Inc. v. United States, 21 Cl. Ct. 31, 39 (1990) (following DeVito). "The essence of the waiver of the delivery date doctrine as explained in DeVito ... is that through Government actions or inactions, and contractor reliance thereon, the Government is estopped from enforcing a specified contractual delivery date." Indemnity Ins. Co. v. United States, 14 Cl. Ct. 219, 222 (1988) (quoting Brent L. Sellick, ASBCA No. 21,869, 78-2 B.C.A. (CCH) 13,510, at 66,194-95 (Oct. 20, 1978)).

203. See, e.g., Alpine Constr. Co. v. Water Works Bd., 377 So. 2d 954, 955 (Ala. 1979).

204. Wagstaff v. Remco, Inc., 540 P.2d 931, 933 (Utah -1975).

205. Most states have enacted statutes that legitimize such retainages at between $5 \%$ to $10 \%$ of each progress payment, especially in public contracts, to discourage abandonment by the contractor. See, e.g., ARIz. REV. STAT. ANN. § 41-2576 (1992) (10\%); MO. 
contractor has satisfactorily completed the project. Unfortunately, disputes often arise regarding the amount of nonpayment beyond this set level necessary to qualify as a "substantial breach." Such was the case in Vinen Corp. v. Alan W. Nau Contracting, Inc., ${ }^{206}$ in which the court made a valiant effort to clear up the mystery but was, in the end, unsuccessful. At issue in Vinen Corp. was whether the plaintiff contractor was subject to damages for walking off a job after the defendant relied on a "self-help set-off procedure" to withhold $\$ 11,000$ from a progress payment. ${ }^{207}$ The trial judge responded in the affirmative, reasoning that "I do not find that $[\$ 11,000]$ is . . a substantial amount considering the $[\$ 211,000]$ figure in the contract price ... Vimen's walk-off was a breach ... and was not justified by Nau's nonpayment." ${ }^{208}$ On appeal, the decision was reversed. The higher court ruled,

It is true that it has been held that where a contract is entire so that the payment of the consideration in installments is not for a particular performance, nonpayment does not justify the contractor in failing to complete the work. But there is contrary authority.... We find it impossible to believe that in a najor construction project the parties would expect that a subcontractor would be obliged to continue working even though there were material delays in payment to it. ... [H]ere there was a substantial underpayment.... [P]laintiff was justified im discontinuing performance. ${ }^{209}$

Obviously, the government's withholding of damages should constitute breach if the government actually is responsible for the construction delay. But as Vinen Corp. indicates, the concept of payment due provides contractors with another ambiguous rule with which they may challenge even a legitimate withholding of hiquidated damages. ${ }^{210}$ To counter this danger, some jurisdictions

ANN. STat. § 34.057(1) (Vernon 1992) (5\%); N.Y. GEN. MuN. LAW § 106-b (McKinney 1986) (5\%).

206. 557 A.2d 1056 (N.J. Super. Ct. App. Div. 1989).

207. Id. at 1058.

208. Id.

209. Id. (quoting Zulla Steel, Inc. v. A \& M Gregos, Inc., 415 A.2d 1183, 1187 (N.J. Super. Ct. App. Div. 1980)). Cases holding that nonpayment does not justify abandonment by the contractor include Stewart v. C \& C Excavating \& Constr. Co., 877 F.2d 711, 714 (8th Cir. 1989) and Dahlstrom Corp. v. State Highway Comm'n, 590 F.2d 614, 616 (5th Cir. 1979).

210. See, e.g., Wilton Corp., ASBCA No. 39,876, 93-2 B.C.A. (CCH) I 25,897, at 128,825 (Feb. 17, 1993) (involving argument that "the Government interfered with ... 
have statutorily authorized unilateral assessment of fixed amounts, placing the burden on the contractor to establish whether the assessment is appropriate. ${ }^{211}$ These few statutes have not completely solved the problem, however, because contractors still consistently seem to believe that owners never are justified in withholding payment as long as the contractors keep working.

\section{EXISTING LEGISLATIVE INTERVENTION}

Several jurisdictions have created legislation that sets forth specific criteria under which stipulated damages are to be presumed valid. ${ }^{212}$ The enactment of these statutes is evidence that the common law framework is, in fact, confusing. Moreover, these statutes deal primarily with public construction contracts, confirming the need for added certainty in that context. California's legislation $^{213}$ comes closest to the ideal solution to the liquidated damages problem and even makes an attempt at reforming private, as well as public, construction contracts. Such statutes still are deficient in several important respects, including their failure to address extrinsic defenses. But if the number of disputes reaching the courts is any indication, each statute has been fairly successful in achieving its goals.

\section{A. The California Statutes}

In 1969, the California Law Revision Commission was authorized to study whether the state liquidated damages law should be revised. By 1977, the Commission had published its final conclusions, ${ }^{214}$ and the resultant statutory modifications have made Cali-

performance [of a contract] by unreasonably . . . delaying payment"); Amp-Rite Elec. Co. v. Wheaton Sanitary Dist., 580 N.E.2d 622, 643 (11l. App. Ct. 1991) (involving claim that government breached its contract by merely assessing liquidated damages).

211. See GA. CODE ANN. \& 13-11-5 (Supp. 1994) (providing that in regard to prompt payments on contracts, "[n]othing in this chapter shall prevent the owner from withholding payment to its contractor because of . . . unsatisfactory job progress"); Mo. ANN. STAT. \& 34.057 .5 (Vernon 1992) (stating procedure for making progress payments under public works contracts) ("Nothing in this section shall prevent the owner from withholding payment or final payment from the contractor. . . Reasons for withholding shall include . . . liquidated damages [and] unsatisfactory job progress.").

212. See supra notes $69-72$ and accompanying text (regarding the effects of a presumption of invalidity and the effects of a presumption of validity).

213. Act of June 30, 1977, cb. 198, 1977 Cal. Stat. 718, 718-22.

214. California Law Revision Comm'n, Recommendation Relating to Liquidated Damages, 13 CAL. L. REvision COMM'N ReP. 1737-64 (1976) [hereinafter California Recom- 
fornia's law of public construction contracts unique. Prior to the Commission's study, California relied on statutes similar to those in many other states that were based on standards espoused by the common law. ${ }^{215}$ Unfortunately, as in many other states, "[t]he judicial decisions interpreting and applying these requirements severely limit[ed] the use of liquidated damages provisions ... [because the statutes reflected] soine bias against [such] provisions."216 The Commission, recognizing both the benefits and the dangers of liquidated damages provisions, argued that
their use should be encouraged where the contracting parties have relatively equal bargaining power. In such cases, the pro- visions serve many useful and socially desirable purposes, particu- larly including avoidance of the cost, the uncertainty, and the delay of litigating the issue of damages. However, the limitations of the existing law should be retained and additional protection provided in cases where the parties have substantially unequal bargaining power. ${ }^{217}$

To remedy the situation, the Commission recommended that the then-existing law remain unchanged for transactions involving consumer contracts, due to the risk of oppressive results. Such transactions included consumer services, the sale or leasing of personal property, and the sale or leasing of residential housing. ${ }^{218}$ In public and private construction contracts, however, in which the parties were considered to be on more even footing, the Commission's suggested changes enabled owner and contractor "to agree to reasonable liquidated damages [for delay] with assurance that the provision will be held valid." ${ }^{\prime 219}$ Only if the damages were

mendation].

215. Id. at 1739 n.2. The prior California statutes, CAL. CIv. CODE $\$ \S 1670-1671$

(1872) (amended 1977), read:

1670. Every contract by which the amount of damage to be paid, or other compensation to be made, for a breach of an obligation, is determined in anticipation thereof, is to that extent void, except as expressly provided in the next section.

1671. The parties to a contract may agree therein upon an amount which shall be presumed to be the amount of damage sustained by a breach thereof, when, from the nature of the case, it would be impracticable or extremely difficult to fix the actual damage.

Cf. supra note 85 (citing other statutes regarding liqnidated damages).

216. California Recommendation, supra note 214 , at 1739.

217. Id. at 1741; see also infra note 251 and accompanying text.

218. California Recommendation, supra note 214, at 1741-1742.

219. Id. at 1742 . 
shown "to be manifestly unreasonable under the circumstances existing at the time the contract was made" would they be held void. ${ }^{220}$

Also significant among the changes implemented by California in the 1970s was the enactment of separate statutes ${ }^{21}$ applying the standard of validity specifically to liquidated damages for delay in various types of public construction contracts. ${ }^{222}$ This focused treatment revealed the state's special concern in regard to government projects. The California Civil Code sections that previously had represented a codification of the common law standard ${ }^{23}$ were inodified to exclude public construction contracts from their purview. ${ }^{224}$ In the other already existing relevant statutes, the primary change consisted of incorporating a new approacli by the inclusion of one sentence: "The sum so specified is valid as liquidated damages unless inanifestly unreasonable."22s

The California legislation differs from the common law most dranatically in that it shifts the burden to the contractor to establish that the government is not entitled to assess liquidated damages, ratlier than forcing the government to establish that it is so entitled. Unfortunately, the statutes maintain the uncertainty of the penalty defense and do not address extrinsic defenses whatsoever. As a step in the riglit direction, however, California's progress is unique. Silva \& Hill Construction Co. v. Employers Mutual Liability Insurance $\mathrm{Co}^{226}$ provides an eloquent critique of the state's motivation in attempting reform:

[Government Code section] 14376 is an integral part of a comprehensive statutory scheme governing the erection, con-

220. Id. at 1746.

221. See Act of June 30, 1977, ch. 198, 1977 Cal. Stat. 718, 718-22. Chapter 198 amended the following statutes: CAL. CIV. CODE $\$ 1671$ (1872); CAL. Gov'T CODE $\S 14376$ (1955); CAL. Gov'T CODE § 53069.85 (1973); CAL. STS. \& HIGH. CODE § 5254.5 (1959). It also enacted CAL. EDUC. CODE $\$ 92050$ (1977). Several of these statutes have been further amended or repealed and replaced since 1977. See infra notes 227-30; see also Review of Selected 1977 California Legislation, 9 PAC. L.J. 281, 325 (1978) (explaining chapter 198).

222. California Recommendation, supra note 214, at 1762.

223. CAL. CIV. CODE $\$ \S 1670-1671$ (1872) (repealed 1977).

224. CAL. Crv. CODE $\S 1671$ (West 1985). Note that CAL. Civ. CODE $\S 1670$ (1872) was repealed as part of chapter 198.

225. CAL. GOV'T CODE \& 14376 (1977); CAL. Gov'T CODE $\$ 53069.85$ (1977); CAL. STS. \& HIGH. CODE $\S 5254.5$ (1977). These statutes have been amended or repealed. See infra notes 227-30.

226. 97 Cal. Rptr. 498 (Ct. App. 1971). 
struction, repair and improvement by the state of its buildings, roads and other structures. The statute represents an express legislative effort to protect the State of California from the consequences of delay in the completion of state construction projects. As such, section 14376 serves to protect the state in two ways. First, it insures that the state will be at least partially reimbursed for additional costs, lost public benefits, overhead expenses, etc., incurred as a result of the contractor's overrun. Secondly, it encourages the contractor to work towards a timely completion of the work. ${ }^{227}$

Other parts of this "comprehensive statutory scheme" protect local municipalities, ${ }^{228}$ highway projects, ${ }^{229}$ and the University of Cahfornia. ${ }^{230}$

\section{B. The New York Statute}

New York's applicable legislation facilitates the use of liquidated damages provisions in very exclusive circumstances. The

227. Id. at 500 (emphasis added) (citation omitted); see also Wiechman Eng'rs v. State, 107 Cal. Rptr. 529, 537 (Ct. App. 1973) (following the result in Silva \& Hill). CAL. GOV'T CODE $\S 14376$ was repealed in 1981 and replaced without significant changes by Cal. Pub. Cont. Code $\S 10226$ (West $1985 \&$ Supp. 1994). See 1981 Cal. Stat., State Contract Act, ch. 306, 1981 Cal. Stat. 1442. Section 10226 currently reads:

Every contract shall contain a provision in regard to the time when the whole or any specified portion of the work contemplated shall be completed, and shall provide that for each day completion is delayed beyond the specified time, the contractor shall forfeit and pay to the state a specified sum of money, to be deducted from any payments due or to become due to the contractor. The sum so specified is valid as liquidated damages unless manifestly unreasonable under the circumstances existing at the time the contract was made. A contract for a road project, flood control project, or project involving facilities of the State Water Resources Development System may also provide for the payment of extra compensatiou to the contractor, as a bonus for completion prior to the specified time, the provision, if used, to be included in the specifications and to clearly set forth the basis for the payment.

228. CAL. Gov'T CODE \& 53069.85 (West 1983 \& Supp. 1994). See also Review of Selected 1973 California Legislation, 5 PAC. L.J. 205, 486 (1974):

Because many public contracts are required to be awarded through the bidding process, it is impossible in this situation to negotiate a liquidated damages clause under Section 1671 of the Civil Code. Local agencies have therefore been effectively prohibited from including provisions for such damages in their contracts. Section 53069.85 rescues local agencies from their plight by giving them authority similar to that granted the state under Section 14376 [(now CAL. PUB. CONT. CODE § 10226) (West 1985 \& Supp. 1994)].

229. CAL. STS. \& HIGH. CODE $\S 5254.5$ (1977). This statute was repealed in 1982 and replaced without significant changes by CAL. PUB. CONT. CODE $\$ 20427$ (West 1985). See 1982 Cal. Stat. 1940.

230. CAL. EDUC. CODE $\S 92050$ (West 1989). 
statute appears to be an anomaly, buried deep within the state's chapter on education law. ${ }^{231}$ Notably, the statute seems to take for granted that the owner may pursue self-help by withholding payments. ${ }^{232}$ It also permits a good-faith approach by owners, in that the inclusion of liquidated damages provisions is not mandatory, and the owner is free to remit any sums withheld ${ }^{233}$ if, for example, the contractor picks up the pace. Most striking, however, are the statute's limitations. It applies only to construction and procurement contracts executed by school boards, and it applies only to boards in cities of one million people or more. ${ }^{234}$ The New York City school board, therefore, is the only entity to which the statute applies. Why New York initially placed such restrictions on the legislation and why the state has not applied it to other situations in the last forty-seven years is unclear; perhaps it was an experiment. What is clear, however, is that the statute casts a new light on the otherwise cloudy law of liquidated damages in New York. It represents a codification, most likely inadvertent, of Southwest Engineering Co. v. United States ${ }^{235}$ and creates a presumption of validity, at least when the contractor pursues the "actual damages" defense.

Caselaw citing the New York statute is extremely rare, which may be why it seems to have been forgotten by the state legisla-

231. N.Y. Educ. LAw $\S 2556(11)$ (McKinney 1993). Note that the relevant subsection, (11), is also buried deep within N.Y. EDuC. LAw $\S 2556$ itself. The statute was enacted in 1947 and reads:

(11) In all contracts by a board of education, in a city having a population of one million or more, for the construction, repair, alteration, or remodeling of buildings or for the purchase of supplies, furniture or equipment, a stipulation may be inserted for liquidated damages for any breach, failure, or delay in the performance thereof; and such board of education is authorized and empowered to remit the whole or any part of such damages as in its discretion may be just and equitable; and in all suits commenced on any such contracts or on any bond given in connection therewith it shall not be necessary for such board, whether plaintiff or defendant, to prove actual or specific damages sustained by reason of any such breach, failure, or delay, but such stipulation for liquidated damages shall be conclusive and binding upon all parties.

232. See id. In other words, the owner cannot "remit" damages unless he has already withheld them.

233. Id. Statutes that require the government to include liquidated damages provisions regardless of the circumstances severely constrain the owner's discretion and diminish the legitimacy of such damages in the eyes of courts and contractors. See generally Dix, supra note 43 , at 251-52 (arguing that mandatory provisions are the least likely to be enforced).

234. N.Y. EDUC. LAW § 2556(11).

235. 341 F.2d 998 (8th Cir.), cert. denied, 382 U.S. 819 (1965); see infra text accompanying notes $271-76$. 
ture. The most significant is Kelly $v$. Board of Education, ${ }^{236}$ in which an electrician contracted with the New York City Board of Education to install fixtures in a particular school building. Because the contractor failed to notify the Board that the fixtures contemplated could not be procured for several inonths, he was unable to secure a contract extension. Performance consequently took 242 days instead of the agreed-upon 120 days. ${ }^{237}$ The trial judge, whose decision ultimately was affirmed by the New York Court of Appeals, ${ }^{238}$ ruled that the provisions of the New York statute were sufficient to relieve the Board of the need to show actual damages; as a result, liquidated damages for the delay were held to be appropriate. ${ }^{239}$ Like the California legislation, New York's statute represents a positive step, but it also is ultimately unsatisfactory because it is not comprehensive and does not go far enough in alleviating uncertainty in the law of liquidated damages.

\section{The Florida Statute}

Like New York's statute, the Florida legislation ${ }^{240}$ promotes

236. 169 N.Y.S.2d 405 (Sup. Ct. 1957).

237. Id. at 406 .

238. Kelly v. Board of Educ., 201 N.Y.S.2d 779 (N.Y. 1960).

239. Kelly, 169 N.Y.S.2d at $406-07$.

240. FLA. STAT. ANN. § 337.18 (West 1994). The relevant text of the statute reads:

(2) Every contract let by the department for the performance of work shall contain a provision for payment to the department by the contractor of liquidated damages due to failure of the contractor to complete the contract work within the time stipulated in the contract or within such additional time as may have been granted by the department. The contractual provision shall include a reasonable estimate of the damages that would be incurred by the department as a result of such failure. The department shall establish a schedule of daily liquidated damage charges for construction contracts entered into by the department, which schedule shall be incorporated by reference into the contract. ... The schedule shall be divided into the following categories, based on the original contract amounts:
(a) $\$ 50,000$ and under;
(b) Over $\$ 50,000$ but less than $\$ 250,000$;
(c) $\$ 250,000$ or more but less than $\$ 500,000$;
(d) $\$ 500,000$ or more but less than $\$ 2,500,000$ :
(e) $\$ 2,500,000$ or more but less than $\$ 5,000,000$;
(f) $\$ 5,000,000$ or more but less than $\$ 10,000,000$;
(g) $\$ 10,000.000$ or more but less than $\$ 15,000,000$;
(h) $\$ 15,000,000$ or more but less than $\$ 20,000,000$; and
(i) $\$ 20,000,000$ and over.

Any such liquidated damages paid to the department shall be deposited to the credit of the fund from which payment for the work contracted was authorized. 
the use of liquidated damages in limited circumstances, namely in public construction contracts related to transportation. The most interesting aspects of the statute include the following: (1) the use of liquidated damages provisions for delay in transportation contracts is mandatory; ${ }^{241}(2)$ the statute dictates that such provisions nust be drawn from a "schedule of daily liquidated damage charges" with fixed amounts corresponding to nine gradations of the total contract price; ${ }^{242}$ (3) the statute paradoxically seems to call for a case-by-case mquiry by the state into the damages that may result from breach and requires the provision to be tailored to those damages, ${ }^{243}$ and (4) if timely completion of the project is "essential to the public health, safety, or welfare, or is cost beneficial on a revenue-producing project," the owner may provide for a per diem bonus for early completion and, apparently, for damages in excess of those scheduled for late completion. ${ }^{244}$

The Florida legislation implies that any liquidated damages provision falling within a department's scheduled guidelines is presumed to be valid. By doing so, the statute goes farther than the laws in California and New York because it sets precise limits on those damages that are considered "reasonable." It also gives due attention to injury to the public from delayed completion of government projects. ${ }^{245}$ Cases citing the statute are nonexistent because it is relatively new and, perhaps, because it has succeeded in reducing the uncertainty that plagues the common law. Several notable cases in other jurisdictions have approved the use of a similar "schedule" of damages based on contract price. ${ }^{246}$

(5)(a) If the department determines and adequately documents that the timely completion of any project is essential to the public health, safety, or welfare, or is cost beneficial on a revenue-producing project, the contract for such project may provide for an incentive payment payable to the contractor for early completion of the project or critical phases of the work and for additional damages to be assessed against the contractor for the completion of the project or critical phases of the work in excess of the time specified. ... Any liquidated damages provided for under subsection (2) ... and any additional damages provided for under this subsection shall be payable to the department because of the contractor's failure to complete the contract work within the time stipulated in the contract or within such additional time as may have been granted by the department.

241. Id. $\S 337.18(2)$.

242. Id. $\S 337.18(2)(\mathrm{a})-(\mathrm{i})$.

243. Id.

244. Id. $\S 337.18(5)(a)$.

245. E.g., id. $\$ 337.18(2)(\mathrm{b})$ (authorizing liquidated damages for delays and inconveniences to the public, including continuing detours).

246. P \& D Contractors, Inc. v. United States, $25 \mathrm{Cl}$. Ct. 237, 240 (applying figures 


\section{A MOVE TOWARDS CERTAINTY AND UNIFORMITY}

\section{A. Unique Public Construction Contracts}

As discussed in Part II, inconsistent standards and rules regarding burden of proof and the penalty defense apply to liquidated damages in all types of contracts, while many questionable extrinsic defenses apply to all construction contracts. ${ }^{247}$ Some skeptics may see this "commonality of confusion" as justification for an all-or-nothing approach to liquidated damages reform: change is necessary and practicable either in all contexts or in none. Yet despite the fact that the law of liquidated damages refers to an expansive and diverse group of provisions and contract types, liquidated damages in public construction contracts should be treated differently, because such contracts are unique. The circumstances surrounding contracts in this discrete area of the law can be as diverse as in any other, but all public construction contracts share several iniportant characteristics that make reform imperative, viable, and justifiable.

The nature of the parties, the significance of the projects, and the overall impact of breach in public construction contracts are often very different fron those in other types of arrangements. While the various rationales for maintaining uncertainty in the law in the context of private contracts-most relating to the avoidance

established in navy contracting manual to general construction contracts), aff d, 985 F.2d 583 (Fed. Cir. 1992); Fred A. Arnold, Inc. v. United States, 18 Cl. Ct. 1, 12 (1989) (same); Gustafson \& Co. v. State, 156 N.W.2d 185 (S.D. 1968). The contract in Gustafson contained the following graduated scale:

$\begin{array}{lc}\text { Original Contract Amount } & \text { Damages Per Day } \\ \$ 0-25,000 & \$ 42.00 \\ 25,000-50,000 & 70.00 \\ 50,000-100,000 & 105.00 \\ 100,000-500,000 & 140.00 \\ 500,000-1,000,000 & 210.00 \\ 1,000,000-2,000,000 & 280.00 \\ 2,000,000 & 420.00\end{array}$

Id. at 187. The court concluded that "the amount stipulated ... is not, as a matter of law, disproportionate to any and all damage reasonably to be anticipated from the unexcused delay in performance." Id. at 189; see also Melwood Constr. Corp. v. State, 481 N.Y.S.2d 289, 292 (Ct. Cl. 1984) (upholding New York Department of Transportation schedule of damages), aff'd, 501 N.Y.S.2d 604 (App. Div. 1986).

247. See supra Section II(B). 
of penalties ${ }^{248}$-are difficult to refute in that context, the common characteristics of public construction contracts mandate that changes be made to uphold the benefits of liquidated dainages. The courts should continue to protect contractors from oppressive conditions; they simply should not be as protective of contractors involved in the public construction industry, because the circumstances are unique and the cost implications for taxpayers are too great. The most significant differences between public construction contracts and other contracts include the following:

(1) even when no actual damages occur, intangible damages to the public are consistently present when delay occurs on public construction projects; thus compensation for such harms is a consistent characteristic of liquidated damages provisions in public construction contracts, ${ }^{249}$

(2) efficient breach is highly unlikely in the public construction industry, ${ }^{250}$

(3) truly unequal bargaining over liquidated damages is rare in the public construction industry,

248. See supra notes $62-66$ and accompanying text.

249. Cf. supra note 62 and accompanying text (arguing that compensation should be the only objective of fixing damages in advance). Therefore, even if courts are less protective of contractors, the compensatory objectives behind the system of contract remedies would not be eliminated, but effectively maintained. Greater attention merely should be paid to the public's need for compensation for both tangible and intangible damages. See infra notes 279-86 and accompanying text. Furthermore, liquidated damages should be used only when the government makes a good-faith effort to articulate some legitimate form of intangible or tangible public harm that could be caused by completion delay. See infra note 263 and accompanying text. Finally, the opportunity should remain for the contractor to take the initiative and challenge an unreasonable assessment under the unconscionability doctrine. See infra note 256 and accompanying text.

250. Cf. supra note 63 and accompanying text (arguing that liquidated damages deter efficient breaches). Because contractors generally operate within a limited regional area, and because most government entities are statutorily bound to award publicly bid contracts to the "lowest responsible bidder;" see, e.g., CONN. GEN. STAT. ANN. \& 4a-59(c) (West 1994); any contractor interested in maintaining a business would be unlikely to drop one project halfway through in favor of a "better" one. In determining whether a contractor is "responsible," contract administrators typically are required to consider "past performance" of the bidder. Id. This process entails an evaluation of "the skill, ability and integrity of the bidder in terms of the bidder's fulfillment of past contract obligations and his experience or lack of experience ...."Id. Furthermore, because of the massive cost overruns involved in most abandonments of public contracts, it is unlikely that, in the grand scheme of things, the overall utility level to society will be increased if a contractor repudiates one project for another.

251. Cf. supra note 64 and accompanying text (arguing that liquidated damages may be the result of unequal bargaining). See generally California Recommendation, supra note 214, at 1742 (implying that commercial parties have relatively equal bargaining power); 
(4) the risk of breach-inducing activities in order to collect damages is not significant in the public construction industry; $;^{252}$ and

(5) in pubhic construction contracts, policies that hold some liquidated damages unenforceable because of extrinsic circumstances should be reconsidered. ${ }^{253}$

Only public construction contracts support all of these rationales, which considered together repudiate the justifications for extensive enforceability rules for liquidated damages. ${ }^{254}$ Other types of agreements, while similar to public construction contracts in many ways, are not equivalent; even private construction contracts consistently fail to satisfy rationales (2), (3), and (4). With these reali-

Sweet, supra note 4, at 122 (describing the public bidding process). First, bargaining over liquidated damages provisions is generally not an issue in the public construction industry due to the bidding process. In that process. contractors typically contemplate the possibility that damages for delay may be imposed and adjust their bids accordingly. Sweet, supra note 4, at 122 . Negotiation of any particular clause is not required to make it effective. JEM Dev. Corp., ASBCA No. 45,912, 94-1 B.C.A. (CCH) I 26,407, at 131,367 (Oct. 5, 1993). Second, construction contractors "are not so unsophisticated as to merit special protection by the courts." Sweet, supra note 4, at 122. Cf. Central Steel Drum Co. v. Gold Cooperage, Inc., 491 A.2d 49, 55 (N.J. Super. Ct. App. Div. 1985) (citing cases to the effect that only when one party is a consumer should courts be protective), overruled on other grounds by Kutzin v. Pirnie, 591 A.2d 932 (N.J. 1991). The reality is that absent coercion, contractors do not enter into contracts if it is not in their best interests to do so. Finally, part of the thesis of this Note is that greater concern should be given to the general public vis-à-vis the contractor.

One additional issue that must be considered is the fact that many government entities rely in large part on standard form contracts drafted by a central authority. See, e.g., supra text accompanying note 18. These forms typically are used to avoid the time and expense necessary to draft a detailed, individualized contract. Unfortunately, courts often interpret contracts very strictly in the context of extrinsic defenses like apportionment (see supra subsection $\Pi(B)(2)$ ), abandonment (see supra subsection $\Pi(B)(3)$ ), and substantial completion (see supra subsection $\Pi(B)(4)$ ). Thus a municipality that relies on standard forms without provisions addressing these questions may actualiy be in a bargaining position weaker than that of the contractor, who seems to reap all the benefits from a contract that is ambiguous concerning stipulated damages.

252. Cf. supra note 65 and accompanying text (arguing that liquidated damages may lead owners to induce breaches by contractors). Most government entities are not out to make a profit when they decide to undertake a public construction project. See, e.g., Public Health Trust v. Romart Constr. Inc., 577 So. 2d 636, 638 (Fla. Dist. Ct. App. 1991); Melwood Constr. Co. v. State, 481 N.Y.S.2d 289, 291 (Ct. Cl. 1984), aff'd, 501 N,Y.S.2d 604 (App. Div. 1986). For that reason, and because the potential for cost overruns and political fallout is so great, they have little incentive to induce a breach.

253. Cf. supra note 66 and accompanying text (arguing that liquidated damages are sometimes unenforceable because of circumstances extrinsic to the contract per se). Compare supra subsections II(B)(2)-(6) with infra subsections IV(B)(2)-(6), respectively.

254. See supra notes $62-66$ and accompanying text. 
ties in mind, one can approach a modification of the common law standards as they apply to public construction contracts confident that the equities support such reform.

In sum, the statutory creation of a universal presumption of validity and enforceability for fixed.delay damages that meet certain parameters in public construction contracts would be the most effective solution to the problems plaguing the law of liquidated damages. Such a statute would not punish contractors, but merely would shift the target of protection away from the lone contractor and towards the general public. ${ }^{255}$

\section{B. A Uniform Liquidated Damages Statute}

A presumption of validity and enforceability under a uniform statute would operate, when delay is shown, in favor of the owner, allowing a unilateral withholding of payment based on the relevant damages provision as the proper recovery. The contractor would have the opportunity to overturn the assessment, but only through evidence of unconscionability. ${ }^{256}$ Thus only damages that "shock

255. See Appendix. The full text of a proposed model statute is set forth therein. The statute is based, in part, on a variety of already existing statutory sources, including the U.C.C., the Federal Acquisition Regulation, see 48 C.F.R. $\S 12.202$ (1993), and the state statutes dehineated supra Part III. It also attempts, of course, to solve the problems of liquidated damages for contractor delays that have not been addressed by the current law. Finally, in its ultimate form the statute might deal with related issues as well, such as contractor recovery for government-caused delay or retainage procedures.

256. Unconscionability is a better standard than the current law of penalty because it is "a unifying fairness principle [that] presents a less costly alternative to the sweeping invalidation powers exercised under the penalty rule." Charles J. Goetz \& Robert E. Scott, Liquidated Damages, Penalties, and the Just Compensation Principle: Some Notes on an Enforcement Model and $a$ Theory of Efficient Breach, 77 Colum. L. REv. 554, 594 (1977).

It is helpful at this point to review the doctrine of unconscionability by focusing on the statement of the law in the U.C.C. The enactment of U.C.C. \& 2-302 (1990) was "[t]he most important development in the consideration of the unconscionability doctrine ... [because it] has far-reaching influence throughout contract law, not just in cases governed by Article 2." HowaRD O. HUNTER, MODERN LAw OF CONTRACTS I 19.06[2] (rev. ed. 1993). Section 2-302 reads:

(1) If the court as a matter of law finds the contract or any clause of the contract to have been unconscionable at the time it was made the court may refuse to enforce the contract, or it may enforce the remainder of the contract without the unconscionable clause, or it may so limit the application of any unconscionable clause as to avoid any unconscionable result.

(2) When it is claimed or appears to the court that the contract or any clause thereof may be unconscionable the parties shall be afforded a reasonable opportunity to present evidence as to its commercial setting, purpose and effect to aid the court in making the determination. 
the judicial conscience" and are imposed without adequate warning would be overturned, and the burden of persuasion would remain at all times with the contractor.

A uniform statute would require, after a two-year grace period, ${ }^{257}$ scrupulous documentation by the government regarding its reasons for using liquidated damages, as well as detailed descriptions of such provisions and related clauses in solicitation and contract documents. ${ }^{258}$ To that end, the statute would incorporate Florida's statutory concept of a schedule of maximum liquidated damages based on total contract price. ${ }^{259}$ Once the government has satisfied the statutory requirements for such schedules, the per diem amount assessed would be presumed conscionable, valid, and enforceable if within the limit set by the appropriate schedule. ${ }^{260}$

In practice, a determination of unconscionability is a question of law dependent on a court's interpretation of the facts peculiar to the case. Chateaugay Corp. v. Northern States Contracting Co., 162 B.R. 949, 960 (Bankr. S.D.N.Y. 1994).

Notably lacking in $\S 2-302$ is a precise definition of the term "unconscionability." Courts commonly distinguish between procedural and substantive unconscionability:

Substantive unconscionabilty involves questions about the fundamental fairness of the agreement or clauses within the agreement: Regardless of the identity of the parties, is this a clause or a contract that should be enforced by a court? Procedural unconscionability involves questions about the manner in which the agreement was reached: Did one party adequately explain the content of the agreement to the other? Was the explanation in a language readily understood by the other party? Were there sharp practices or overreaching? Did one party take advantage of the other's lack of experience or naivete?

HUNTER, supra, I 19.06[3]: A finding of unconscionability requires the party invoking the doctrine to show both procedural and substantive unfairness. Chateaugay Corp., 162 B.R. at 959-60. Moreover, there is a presumption of "conscionability" in contracts between parties in a commercial setting because most such parties "are (or should be) sophisticated enough to protect their own interests in negotiating transactions." HUNTER, supra, I 19.06[4].

257. Within the two-year period the government would be able to rely on standard form contracts and prepare for the slightly more rigorous procurement procedures that would be required by the statute.

258. See Appendix \$\$ 3-5. Providing contractors with abundant notice, especially in the solicitation materials, would help the government avoid instances of procedural unconscionability; articulating a legitimate basis for the damages would help the government avoid instances of substantive unconscionability.

259. See supra note 240 and accompanying text. The California and New York statutes detailed supra Sections III(A) and (B) do not go quite as far in establishing criteria to determine whether stipulated damages are enforceable. Such concrete standards are necessary, however, to truly eliminate the need for courts to perform case-by-case reviews regarding reasonableness.

260. See Appendix $\S \S 6,15(2)$. The government would not be absolutely prohibited from setting damages outside the limits of its schedule, but such damages would be outside the protection of the statute and would be presumed unconscionable. The parties must look at the system as fair in the long run; occasions in which the actual level of 
The statute would also require the use of bonus payments for early completion whenever liquidated sums are included in a contract. ${ }^{261}$ Finally, the need for appeal would be minimized by the narrow standard of review for unconscionability. ${ }^{262}$ Such a statute would make great strides in protecting the benefits of liquidating damages-reducing the public's costs, conserving judicial resources, alleviating uncertainty regarding risk, and ensuring performance. Yet the system would also protect the rights of contractors to be free from excessive damages and would reward them for efficient performance.

1. Penalty. Under a uniform liquidated damages statute, the need for judicial intervention hopefully would be minimal. For the rare cases when an independent opinion is necessary, the statute should be designed to guide the court to a swift and proper conclusion. Since the doctrine of unconscionability would supplant the penalty defense, many of the interpretive problems of that defense would be avoided. Unconscionability is a much simpler test, without the nuances and loopholes available to the contractor under current law.

The first confusing aspect of the penalty defense, the role of "intent," could be resolved expediently by a uniform statute. The government initially would be required to make a threshold showing of either (1) monetary damages likely to be suffered by the government or (2) at least a colorable potential for harm to the public from delay. ${ }^{263}$ By doing so, the government would estab-

damages are above the amounts set in the schedule would be offset by occasions in which the actual level is below the amounts provided.

261. See id. \$ 7. Each state and/or the federal government would be required to create a fund from which bonuses could be paid; $25 \%$ of all liquidated damages recovered in each jurisdiction would be deposited in the appropriate fund. The implementation of such a bonus payment system would help to minimize the appearance of substantive unconscionability and would ensure that a uniform statute would not merely create windfalls for the government.

262. A finding of unconscionability is a conclusion of law by the trial judge based upon findings of fact. Appellate review of such a finding "is limited to determining whether a trial court's findings are supported by substantial evidence, and if so, whether those findings support the conclusion of law. . . . Substantial evidence is evidence sufficient to persuade a fair minded person of the truth of the declared premise." American Nursery Prods., Inc. v. Indian Wells Orchards, 797 P.2d 477. 481 (Wash. 1990).

263. See Appendix $\S 5(2)$. The owner would not need to persuade the contractor or a court that it was motivated to contemplate liquidated damages by the harm proferred. The owner would need only to meet a simple burden of production, to allow an observer rationally to conclude that the damages decision had not been motivated solely by a 
lish that it had at least contemplated the need for compensation in stipulating damages. Once the court is satisfied, the statute would prohibit any further consideration of the parties' intent. It simply is not relevant to a claim of unconscionability. The court in Wilmington Housing Authority v. Pan Builders ${ }^{264}$ explained this ostensibly startling method of dealing with intent:

Courts adopting this intention criterion have been criticized by numerous commentators for merely paying lip service to the intention of the parties while deciding the cases based on the first two criteria, the certainty of damages and the reasonableness of the stipulated amount. ... The view expressed by these commentators has merit. The intentions of the parties only appears relevant insofar as it is evidenced by the other two criteria. ... As Corbin states, "[I]t appears that the intention of the parties is to control [only] if they intended the right thing." Thus the intention criterion adds nothing to the liquidated damages versus penalty test. ${ }^{265}$

Pan Builders is not entirely correct. The intention criteria does add something to the penalty test: uncertainty, due to inconsistent application and unpredictable effect. By taking it out of the analysis, a more efficient system implicitly would affirm the holdings in cases like Robinson $v$. United States ${ }^{266}$ that cut through the orthodoxy and perimit the use of financial incentives to ensure performance.

The second problematic penalty standard-the concept of "reasonableness"-would act, under a uniform liquidated damages statute, as proxy for what previously was analyzed as "intent." Reasonableness would still be a consideration because unconscionable damages are equivalent, essentially, to extremely unreasonable damages; a determination that damages are unconscionable by necessity requires them to be unreasonable. Adjudicating reasonableness on a case-by-case basis can never completely be avoided; shifting the burden to the contractor and increasing its burden through the use of the unconscionability doctrine, however, would allow the benefits of fixed damages to be fully realized. Again, a uniform statute would allow the contractor to overcoine such a

desire to punish the contractor for breach.

264. 665 F. Supp. 351 (D. Del. 1987).

265. Id. at 354 .

266. 261 U.S. 486,488 (1923); see supra note 92 and accompanying text. 
presumption of validity only witl a persuasive claim of unconscionability. Moreover, allowing the government to use liquidated damages schedules based on the damages experienced in prior similar cases would result in the conservation of significant taxpayer resources. To hold, as some might wish, ${ }^{267}$ that schedules lead to generalized and unreasonable penalties "is tantamount to requiring the Government to 'reinvent the wheel' eacli time it enters into a contract for ... construction ... that is to include a liquidated damages provision."268

To alleviate uncertainty even furtlier, courts sliould be forced to consider whether an amount stipulated bears a conscionable and reasonable relation only to expected damages, rather than to actual damages suffered by the government. ${ }^{269}$ Authorities that apply the "actual damages" test fail to appreciate the parties' need to identify and limit future contingent liability. ${ }^{270}$ An analysis of the circumstances existing at the time of contract formation sliould be controlling because it is an approach "based upon sound reasoning."271 If in the course of events damages for delay prove to be greater than those stipulated, the owner sliould be bound by the contractual amount. ${ }^{272}$ Therefore, courts would not be unfair to hold the contractor to the fixed sum if injury later proves to be less than expected or even nonexistent. ${ }^{273}$ When owners and contractors take a calculated risk and fix damages in advance, courts should permit faultless parties on both sides to "keep the

267. See, e.g., P \& D Contractors, Inc. v. United States, 25 Cl. Ct. 237, 239, aff'd, 985 F.2d 583 (Fed. Cir. 1992).

268. Id. at 240 (quoting Fred A. Arnold, Inc. v. United States, $18 \mathrm{Cl}$. Ct. 1,13 (1989)); see also JEM Dev. Corp., ASBCA No. 45,912, 94-1 B.C.A. (CCH) I 26,407, at 131,366 (Oct. 5, 1993): "It is not necessary that the Government tailor-make the liquidated damages rate for each contract. ... The proper use of [amounts set in the contracting manual] is prima facia evidence that the liquidated damage rate was reasonable."

269. See Appendix § 15(2)(c). This approach is consistent with U.C.C. § 2-302 (1990), which directs a court to determine whether a clause was unconscionable "at the time it was made."

270. Sacks \& Daniszewski, supra note 7, at 15.

271. Southwest Eng'g v. United States, 341 F.2d 998, 1003 (8th Cir.), cerr. denied, 382 U.S. 819 (1965).

272. Id.

273. Id.; see also JEM Dev. Corp., ASBCA No. 45,912, 94-1 B.C.A. (CCH) 26,407 , at 131,367 (Oct. 5, 1993) (holding that issue of whether government incurred actual damages is "legally irrelevant"); Henry Angelo \& Co., ASBCA No. 44,648, 93-3 B.C.A. (CCH) I 26,131, at 129,897 (May 26, 1993) (holding that "whether or not the Government suffered actual damage is irrelevant" because the amount stipulated was reasonable at the time of contracting). 
change,"274 rather than ignoring their agreements. Furthermore, in a government construction projects are almost always public facilities, not profit-making enterprises. ${ }^{275}$ The fact that the owner has suffered hittle or no monetary loss does not, therefore, render a liquidated damages provision "unreasonable,"276 because intangible damages to the public may be significant.

The fimal problematic aspect of the penalty rule, the requirement of uncertainty regarding potential damages, would not be a separate conceru under a umform statute, because the standard is-like intent-not part of the unconscionability doctrine. Yet the issue would be subsumed imto an analysis of unconscionability, so it is important to consider why reform is necessary, especially as uncertainty relates to intangible damages in public construction contracts. Under current law, many disputes over the validity of stipulated damages for delay in government projects turn on this issue alone, ${ }^{277}$ since a reviewing court either will be willing to consider intangible damages to the public, or will not. If the court refuses to recognize intangible damages, then "actual" damages for delay in the completion of most government projects are fairly simple to determine ${ }^{278}$ and the fixed per diem sum will be held to be a penalty.

By contrast, when the owner is able to articulate a plausible need for compensation, a uniform liquidated damages statute would direct a court to presume that delay causes intangible harm to the taxpayers of the type articulated. ${ }^{279}$ This harm, along with any rebuttal evidence from the contractor, subsequently would be considered on those occasions when a court determines whether an amount assessed by the owner was unconscionable. Such an approach accounts for the unique interest of the taxpayers in most public contracts and the indirect ways that they suffer when government projects are not finished on time. ${ }^{280}$ It also considers the

274. Weisfield, supra note 86 , at 996.

275. Public Health Trust v. Romart Constr., Inc., 577 So. 2d 636, 637 (Fla. Dist. Ct. App. 1991).

276. Id.

277. See examples cited supra note 128.

278. Sheak \& Korzun, supra note 12 , at 21 . Such actual damages often may equal zero, since the government is unable to measure harm as most other commercial parties do, e.g., through lost rents or sales.

279. See Appendix § 15(2)(d).

280. Priebe \& Sons v. United States, 332 U.S. 407, 411 (1947) ("[Liquidated damages] are particularly useful ... when damages are uncertain in nature or amount or are un- 
time and expense necessary to make a precise estimate of the public harm; the cost is often prohibitive for government entities, leadimg to the prohiferation of form contracts. ${ }^{281}$

The case of Melwood Construction Corp. v. State 282 justified a presumption of intangible damages. The parties debated a Department of Transportation guideline that provided a schedule of damages for the failure of a contractor to complete work on time. ${ }^{283}$ In ruling that the inconvenience and injury suffered by drivers because of delayed roadwork constituted actual damages to the state ${ }^{284}$ the court affirmed that "[a]lthough a municipality, in its corporate capacity, may suffer no damage from delay ... it may validly contract for liquidated damages for delay in contemplation of the inconvemience and loss which will flow to its inhabitants." 2285 This theory of "municipality as trustee for the public"286 allows the government owner to collect under a liquidated damages provision for an authentic and potentially serious injury. As any driver caught in traffic knows, holding otherwise would have been to ignore reality. ${ }^{287}$

2. Apportionment. A uniform liquidated damages statute would be more comprehensive than any existing legislation because it would explicitly address the most significant extrinsic defenses available to public construction contractors. Once again, the need for judicial consideration of these issues hopefully would be minimal. In responding to the extrinsic defense of mutual responsibili-

measurable, as is the case in many government contracts."); Osceola County v. Bumble Bee Constr., Inc., 479 So. 2d 310, 311 (Fla. Dist. Ct. App. 1985) (denying ability to measure "exact monetary loss" in a public contract); In Bumble Bee the government claimed lost revenue arising out of its inability to attract tourists to its old tourist center, which was described as a "shed," during the period when the tourist center under construction was delayed. Bumble Bee, 479 So. $2 \mathrm{~d}$ at 311 . The appellate court agreed, since the record revealed that after the new center was complete the area tourism volume "more than doubled." Id. Yet by that point the government's use of liquidated damages was rendered pointless; it had been forced to go through a trial and an appeal just because the injury to the public was difficult to measure.

281. See supra note 251.

282. 481 N.Y.S.2d 289 (Ct. Cl. 1984), affd, 501 N.Y.S.2d 604 (App. Div. 1986).

283. Id. at 290.

284. Id. at 293.

285. Id. at 292 (quoting Six Cos. v. Joint Highway Dist. No. 13, 110 F.2d 620, 625

(9th Cir.), rev'd on other grounds, 311 U.S. 180 (1940)) (alteration in original).

286. Id. at 293.

287. See, e.g., supra text accompanying note 32 . 
ty, a uniform liquidated damages statute would insist that all public construction contracts drafted after the date of its enactment include a provision for the apportionment of delay. The provision would also dictate that with a few exceptions, the contractor assumes responsibility for delays caused by circumstances unforeseen at the time of contracting. The underlying purposes of such a clause would be simply to give notice to the contractor and to ensure that courts faithfully pursue apportionment when review is necessary. Such mandates may seem fatuous, but they are no more fatuous than the conclusion by some that applying liquidated damages to apportioned delay is "wrong" or that courts should not endeavor to apportion delay in the absence of express contractual language requiring it. ${ }^{288}$ For simplicity's sake, government entities that rely heavily on standard form contracts without apportionment provisions would be allowed to use such contracts for an additional two years without fear that they will lose their right to apportionment. ${ }^{289}$

A uniform statute, while conceding to those authorities that call for express apportionment provisions by requiring the government to include them im future contracts, would acknowledge reality and generally endorse the common-sense principles of Robinson v. United States ${ }^{290}$ and Tyger Construction Co. v. United States. ${ }^{291}$ Robinson provided the Supreme Court an opportunity to distinguish and limit the United Engineering doctrine, which mandates that courts not apply liquidated damages in cases of mutual responsibility for construction contract delay. ${ }^{292}$ The contract in Robinson was completed 121 days behind schedule, and the defendant owner consequently asserted that it was entitled to withhold liquidated damages. ${ }^{293}$ The plaimtiff contractor responded by contending that the relevant contract provision was unenforce-

288. See supra notes $143-45$ and accompanying text. Such standards must be based on a strange conclusion that parties intend to forgo delay damages in cases of mutual responsibility. Delay is delay, and it should easily be implied that owners want-and need-the same compensation for contractor-caused delay when some fault lies with both parties as when all the fault is with the contractor.

289. Cf. supra notes 251,257 (regarding, respectively, the use of form contracts and other "grace periods" that would be provided by the statute).

290. 261 U.S. 486 (1923).

291. 31 Fed. Cl. 177 (1994).

292. United States v. United Eng'g \& Contracting Co., 234 U.S. 236, 242 (1914); see supra text accompanying noies $146-49$.

293. Robinson, 261 U.S. at 487. 
able because the owner's actions had contributed to the delay. ${ }^{294}$ The trial court found the defendant chargeable for sixty-one days' delay and assessed liquidated damages on that basis. ${ }^{295}$ On appeal, the Supreme Court affirmed, stating,

The fact that the Government's action caused some of the delay, presents no legal ground for denying it compensation for loss suffered wholly through the fault of the contractor. Since the contractor agreed to pay at a specified rate for each day's delay not caused by the Government, it was clearly the intention that it should pay for some days' delay at that rate, even if it were relieved from paying for the other days, because of the Government's action. ${ }^{296}$

United Engineering was distinguishable, the Court held, because in that case the work would have been completed within the contract period but for the government's action. ${ }^{297}$ In other words, the contractor was actually guilt-free, so the liquidated damages provision did not apply.

The proper rules were followed much more recently in Tyger Construction Co., in which the Court of Federal Claims held that "[i]n cases of concurrent delay, where both parties contributed significantly to the delay period by separate and distinct actions, justice requires that the cost of the delay be allocated between the two parties proportionally."298 Although authorities often attribute judicial unwillingness to follow Robinson and Tyger to fears that it is impossible to apportion damages, such categorical statements "are an absurdity."299 "Damages are not being apportioned. ... [Q] Jantum of delay in terms of time is all that is being apportioned. That is an uncomplicated factfinding process." 300

Admittedly, a uniform liquidated danages statute would be least likely to reduce litigation by contractors claiming that delay

294. Id.

295. Robinson v. United States, 57 Ct. Cl. 7, 20-21 (1921), aff'd, 261 U.S. 486 (1923).

296. Robinson, 261 U.S. at 488.

297. Id. at 489 .

298. Tyger Constr. Co. v. United States, 31 Fed. Cl. 177, 259 (1994).

299. Nomellini Constr. Co. v. Department of Water Resources, 96 Cal. Rptr. 682, 686 (Ct. App. 1971).

300. Id. The process would be comparable to the apportionment of fault in the 46 states that apply comparative negligence. The four states that do not apply comparative negligence are Alabama, Maryland, North Carolina, and Virginia. Victor E. SCHWARTZ, COMPARATIVE NeGligenCE $\$ 1.1$ (2d ed. 1986 \& Supp. 1993). 
was not their fault, because on many occasions they are justified. ${ }^{301}$ But if contractors were generally aware that Robinson and Tyger would be followed in circumstances of mutual responsibility, they would be deterred from challenging liquidated damages in cases in which such damages are assessed in good faith. As a final solution, because the statute would need to rely to such a great extent on both parties' good faith to have any hope of reducing apportioument claims, these are the only instances in which the statute would take the drastic step of awarding attorney's fees to the successful party. ${ }^{302}$

3. Abandonment. A new law of liquidated damages in public contracts would respond to the extrinsic defense of abandonment in a manner similar to its response to the apportionment issue. The statute first would give notice to the contractor by requiring that all public construction contracts drafted after the statute's effective date include a provision indicating that any hquidated damages will be enforceable after the contractor's abandonment. Such a requirement would be sensible in that it would allow the owner unilaterally to assess damages only for the period between the scheduled completion date and the repudiation..$^{303}$ Once again, the statute would insist that courts honor the parties' wishes when review is necessary, and a similar two-year grace period would apply to standard form contracts. These mandates may seem as superfluous as those relating to apportionment, ${ }^{304}$ but they similarly would respond to questionable $\operatorname{cases}^{305}$ by endorsing a well-reasoned doctrine articulated elsewhere.

The "elsewhere" for abandonment can be found in Southern Pacific Co. v. Globe Indemnity Co. ${ }^{306}$ which stands as the most articulate, most equitable, and most relevant holding on the issue of whether liquidated damages can be assessed against a contractor

301. See supra text accompanying notes $149-50$.

302. See Appendix $\S \S 8,14(3)-(5)$.

303. If the owner believes it is entitled to apply the per diem amount to additional days, or if the contractor abandons before the scheduled completion date, the owner would have to look to a court to decide the appropriate period. See id. $\S 11$. One possible option would be to allow the owner "[to] show the time that the contractor would have taken to complete the work [had he not abandoned.] ... [T] hat is a question of fact." Southern Pac. Co. v. Globe Indem. Co., 21 F.2d 288, 291 (2d Cir. 1927).

304. See supra subsection IV(B)(2).

305. See infra note 307 .

306. 21 F.2d at 291. 
who abandons a project. The court in that case dictated, in no uncertain terms, the justification for ruling that fixed damages for delay are recoverable when the abandonment occurs after the scheduled completion date: "In such [circumstances] some part of the liquidated damages has accrued before the repudiation. No intelligible reason has been suggested why the owner should lose his right to them because of subsequent repudiation." ${ }^{307}$ Southern Pacific discredited cases to the contrary and has not been effectively challenged by any subsequent decision-with good reason. Discordant holdings encourage breaching contractors to abandon their projects, which increases delay, drives up completion costs, and forces owners to sue to recover anything. In making certain that such tactics would not be successful, a uniform system patterned after Southern Pacific would clearly be an improvement over the current state of the law. ${ }^{303}$

4. Substantial Completion. A uniform liquidated damages statute would seek to resolve both of the problematic aspects of the doctrime of substantial completion. First, the statute would give notice to contractors and courts by mandating that new public construction contracts define "scheduled completion date" as the date when all contemplated obligations in a public construction contract are finished, unless the parties desire otherwise. ${ }^{309}$ Such a definition would only apply the traditional meaning to the term "complete," much like the court in Ledbetter Bros. v. Department of Transportation. ${ }^{310}$ As a result, a liquidated damages provision that

307. Id. (emphasis added). The court iu City of Elmira v. Larry Walter, Inc., 564 N.E.2d 655, 656 (N.Y. 1990), argued that the absence of "clear and unambiguous language ... indicating that [the clause] was also intended to apply to defendant's outright abandonment" is a reason for the owner to lose his rights. But such a reason is not "intelligible" enough to satisfy the Southern Pacific standard, because (1) it is not clear that such language would be upheld in other jurisdictions and (2) it must be based on the strange couclusion that parties intend to forgo delay damages in abandonment cases. As with mutual responsibilty, delay is delay, and it should easily be implied that parties want-and need-the same compensation when the work is abandoned as when it is completed late. Objectively, the standard should go the other way: if parties intend that liquidated damages will not apply in case of abandonment, they should be required to so state, in "clear and unambiguous language."

308. See Appendix \$§ 11, 14(1)-(2).

309. "New" refers to contracts drafted after the enactment of the statute, which also would allow two years for the use of existing form contracts without the correct explicit definition.

310. 314 S.E.2d 761 (N.C. Ct. App. 1984). In Ledbetter Bros., the liquidated damages 
penalizes the contractor for delay would apply to the entire contract, and there would be no cause for debate as to when the project was "substantially complete." Second, as previously discussed the statute essentially would eliminate the penalty defense and would allow liquidated damages to induce performance to a certain extent. Thus the contractor could not raise the thorny issues of "intent" and "uncertainty," and it could question "reasonableness" only as part of a claim of unconscionability. ${ }^{311}$

Vrgora v. Los Angeles Unified School District ${ }^{312}$ explains, without intending to, why only final completion-not substantial completion-should toll the government's assessment of damages for delay; the reason is linked to the concept of intangible damages. The appellant contractor in Vrgora essentially asserted the substantial completion defense, argumg that the school district had occupied and used a portion of the facihty prior to total completion. He insisted that full liquidated damages consequently should not apply, since "the specified daily rate [of damages] is a reasonable approximation of the amount necessary to compensate LAUSD because [it] cannot occupy the entire building." ${ }^{313}$ Presumably, appellant continued, "it would not be a reasonable approximation as to only a portion of the building when another portion is actually occupied." 314 The court, although finding that substantial completion had not occurred, rejected the appellant's contentions on his substantial completion claim:

To hold [for the contractor] ... would thwart one of the major purposes of the allowance of liquidated damages-to provide a

provision took effect on the contractor's failure "to complete the work by the completion date," which was the time when the work was "satisfactorily completed." Id. at 766. Because it would be inconsistent, the court reasoned, "to interpret the contract so as to deny [the government] the major contemplated means of assuring timely completion of the work," liquidated damages should be assessed until final completion. Id.

311. A uniform statute would not prohibit the defense of substantial completion from ever applying in a stipulated damages case. A situation could arise "where the work remaining on a contracted project was so trivial that assessing the entire liquidated amount would result in gross unfairness"-i.e., unconscionability. Reliance Ins. Co. v. Department of Transp., 858 P.2d 1363, 1371 (Utah 1993). Unforeseen circumstances must be present, however, that prevent the contractor from proceeding expediently to final completion. See Appendix § 12(2).

312. 200 Cal. Rptr. 130, 134-35 (Ct. App. 1984)

313. Id. at 134 (emphasis added) (second alteration in original).

314. Id. 
remedy-where damages are not easily ascertainable [as in a public contract].

Thus, while hquidated damages must fit within the conventions of reason, they are not necessarily approximations of actual damage suffered. Correlatively, apportionment of an arguably arbitrary sum could not qualify as a true aliquot apportionment of damages in any real sense of the word. ${ }^{315}$

Ledbetter Bros. and Vrgora stand in direct contrast to cases like Thermodyn Contractors, Inc. v. General Services Administration $^{316}$ and S.L. Rowland Construction Co. v. Beall Pipe \& Tank Corp. ${ }^{317}$ and their reasoning is clearly the better approacl 1 witlı respect to public construction contracts. Determinations regarding exactly when a project is substantially complete "only foster additional and wasteful litigation." 318 Furthermore, if inducing timely completion is to be a permissible objective of liquidated damages, "[i]t would frustrate this policy to allow disputes over substantial performance to render [such] provisions unenforceable." 319 In essence, tolling liquidated damages at "substantial completion," inherent ambiguity aside, is equivalent to creating an artificial demarcation in the damages that accrue under a public contract. If the law allows parties to liquidate damages, it should not tliwart their intentions by setting such a boundary. ${ }^{320}$

5. Waiver. A new system of liquidated damages would also need to deal with the uncertainty caused by the application of the waiver defense. Althougl it perhaps is true that "a stipulation regarding time, though otherwise of the essence, may be waived,"321 such waiver should not be held operable unless explicitly commuricated to the contractor. A uniform statute there-

315. Id. at 135. The fact that substantial completion was found not to have occurred in Vrgora is irrelevant; reasonable persons unight disagree with that finding, and this Note argues inerely that the court's logic in Vrgora should apply in cases in which substantial completion has occurred.

316. GSBCA No. 12,510, 94-3 B.C.A. (CCH) पा 27.071, (July 8, 1994); see supra notes 176-82 and accompanying text.

317. 540 P.2d 912 (Wash. Ct. App. 1975); see supra notes 183-92 and accompanying text.

318. Reliance Ins. Co. v. Department of Transp., 858 P.2d 1363, 1370 (Utah 1993).

319. Id. at 1371.

320. See Appendix $\S 12,14(1)-(2)$.

321. Sheak \& Korzun, supra note 12 , at 24 (quoting 5 WILLISTON, supra note $3, \S$ 856). 
fore would mandate that all public construction contracts drafted after the date of the statute's enactment put contractors and courts on notice by including an explicit-waiver-only provision. ${ }^{322}$ Liquidated damages provisions in construction contracts are designed to represent an agreement at the time the parties execute the contract as to the amount of the government's damages in the event of delay. The possibility of delay is specifically contemplated by the parties as a serious matter. ${ }^{323}$ With this seriousness in mind, a claim of waiver should not be granted lightly. Few circumstances are conceivable in which the completion date of a public construction project suddenly becomes "unimportant"; when questions are raised, however, any doubt should be resolved in favor of the government, and thereby the public. A municipality "does not indicate its intention to 'waive' the contract completion date [merely] by allowing performance to continue [after that date], ${ }^{, 324}$ or by failing to assess stipulated sums immediately. In fact, the government's discretion in withholding and remitting damages is sometimes essential to convince the contractor and the courts that it is acting in good faith. ${ }^{325}$ Waiver, therefore, should be found only if express, in order to maximize the benefits of liquidated damages. ${ }^{326}$

322. The statute once again would allow two years for those government entities relying on form contracts to catch up.

323. Michael G. Long, Waiver of the Contract Completion Date in Government Contracts, The Construction LAW., Apr. 1992, at 3, 4; see also Alpine Constr. Co. v. Water Works Bd., 377 So. 2d 954, 955 (Ala. 1979).

324. Long, supra note 323 , at 4.

325. See, e.g., N.Y. EDUC. LAW \& 2556(11) (McKinney 1993) ("[The board] is authorized and empowered to remit the whole or any part of such damages as in its discretion may be just and equitable."). For a uniform statute's potential treatment of the issue, see Appendix $\$ 10$.

326. See Appendix $\S \S 13,14(1)-(2)$. In other words, the recommendations of the court in Indemnity Ins. Co. v. United States, $14 \mathrm{Cl}$. Ct. 219 (1988), should be read as strictly as possible:

With ... [liquidated damages] provisions in the contract, detrimental reliance on the contractor's part cannot be found merely from a period of Government forbearance coupled with continued contractor performance in reliance thereon. ... [W] ith these provisions in the contract Government encouragement to expedite completion during a forbearance period should not be interpreted as a disestablishment of the contractually-prescribed completion date absent further manifestation by the Government that it no longer considered that date to be enforceable.

Id. at 222-23 (quoting Brent L. Sellick, ASBCA No. 21,869, 78-2 B.C.A. (CCH) I 13,510, at 66,194-95 (Oct. 20, 1978)). Therefore, under a uniform statute, only written acknowledgment would qualify as "further manifestation." 
6. Payment Due. A uniform liquidated damages statute would make a true commitment to upholding the benefits of liquidated damages clauses. Because one of these benefits is the conservation of resources, for both the parties and the legal system ${ }^{327}$ the ability of an owner to unilaterally withhold damages is essential for keeping delay cases out of the courts. If an owner were forced to file suit each time it believed liquidated damages should be forthcoming, those dainages would not be liquidated in any sense of the word. Furthermore, a contractor might be encouraged to delay in some instances by gambling on an owner's unwillingness to incur legal expenses.

For all these reasons, the application of statutes like those in Missouri and Georgia ${ }^{328}$ explicitly authorizing the withholding of damages for delay should be universal, codifying the government's common law right "to collect contract debts by set-off against contract payments due its debtors. ${ }^{1329}$ To further strengthen the government's privilege, a uniform statute would require, for notice purposes, that every public construction contract drafted after the statue's enactment include an express withholding provision; a twoyear grace period would accommodate existing form contracts. As always, the opportunity would remain for the contractor to take the initiative and challenge an unconscionable assessment. ${ }^{330}$

\section{CONCLUSION}

Under the current state of the law in most jurisdictions, courts and parties struggle in deciding whether a given liquidated damages provision is a reasonable expectation of future loss or is instead void as a penalty. A lack of predictability im outcomes has created a system that provides contractors with perverse incentives to challenge liquidated damages provisions even when fairly and reasonably administered. Current law consequently negates the benefits of agreed remedies, especially their ability to conserve resources and apportion risk. This inefficacy is most significant in public construction contracts, in which parties typically attempt to apply

327. Restatement (SECOND) of Contracts \& 356(1) cmt. a (1981).

328. See supra note 211.

329. Dan F. Harrison Constr., Inc., ASBCA No. 42,546, 94-3 B.C.A. (CCH) प1 27,050, (July 27, 1994).

330. See Appendix \& 9. 
hquidated damages to project delays. The nature of the parties, the purposes of the projects, and the overall impact of breach are unique in public construction contracts because the cost of delay is passed on to the taxpayers. Therefore, any arguments for nuamtaining uncertainty in the law in the context of private contracts notwithstanding, the characteristics of public construction contracts reveal a need for substantive reform. The courts should continue to protect contractors from oppressive conditions; they simply should not be as protective of contractors involved in the public construction industry, however, because the circuinstances are unusual and the consequences for the taxpayers are too great.

This Note has advocated a conıprehensive, uniform liquidated damages statute to be adopted in all jurisdictions and applied to the public construction industry as the nost effective solution to this problenı. The statute would provide for an overwhelming presuinption of validity in clear factual situations, thereby allowing parties to truly "liquidate" stipulated dainages for delay. Both owners and contractors would benefit, because the statute would encourage only good-faith challenges to, and assessinents of, contracted amounts. It also would require reasonable completion dates and the consistent use of bonus payinents to contractors who coinplete their projects early. In sum, the focus would be placed on the efficient use of tax dollars by providing contractors and owners witlı credible positive and negative financial nicentives. The resultant predictability in the law would reduce both tangible and intangible public harm by preventing parties from relying on courts and by forcing parties to take completion dates seriously. 


\section{APPENDIX: PUBLIC CONTRACT CODE \\ DRAFT UNIFORM LIQUidated DELAY DAMAGES ACT}

\section{\$1. Statement of Purpose.}

(1) This Act represents an express legislative effort to protect the public from the consequences of delay in the completion of government construction projects.

(2) In accordance with subsection (1) the underlying purposes and policies of this Act are

(a) to insure that the government will be reimbursed for additional costs, lost public benefits, overhead expenses, and any other tangible or intangible damages that result from performance after the scheduled completion date;

(b) to encourage contractors, through financial incentives, to work toward the timely completion of their contracts;

(c) to simphify, clarify, and modernize the law governing hquidated delay damages in public construction contracts; and tions.

(d) to make uniform the law among the various jurisdic-

\section{§ 2. Definitions.}

Unless the context otherwise requires, in this Act:

(1) "Actual delay damages" means the additional costs, overhead expenses, and any other provable damages that actually have been suffered by the government as a result of the completion of a public construction contract after the scheduled completion date.

(2) "Appropriate reviewing authority" means the forum of first resort for public contract cases in a particular jurisdiction.

(3) "Bad faith" means lacking in good faith.

(4) "Bonus payment" means the per diem amount set by the parties, in accordance with this Act, to be recoverable by the contractor in the event a public construction contract is completed early.

(5) "Burden of establishing" a fact means the burden of persuading the trier of fact that the existence of the fact is more probable than its nonexistence.

(6) "Cleanup stage" means the portion of a public construction contract during which the contractor has fulfilled all its obligations except for the disposal of work debris, removal of equipment 
and personnel, and performance of other minor completion tasks requested by the government under the authority of the contract.

(7) "Contracting officer" means an agent of the government directly responsible for the administration of a public construction contract and authorized to act on behalf of the government in regard to the contract.

(8) "Contractor" Ineans the private entity executing a public construction contract with the government.

(9) "Good faith" means honesty in fact and the observance of reasonable commercial standards of fair dealing.

(10) "Government" means the federal, state, county, municipal, or other public agency or entity executing a public construction contract with a contractor.

(11) "Intangible delay damages" means the lost benefits, work hours, business profits, and any other damages to the public that may result from the completion of a public construction contract after the scheduled completion date; such damages may be extremely difficult for the government to quantify prospectively.

(12) "Liquidated delay damages" means the per diein amount set by the parties, in accordance with this Act, to be recoverable by the government in the event of delay in the completion of a public construction contract.

(13) The government gives "notice" to the contractor by taking such steps as are required by this Act to inform the contractor in ordinary course whether or not the contractor actually coines to know of it.

(14) "Presumption" or "presumed" means that the trier of law or fact must make a particular conclusion of law or find the existence of the fact presumed unless and until evidence is introduced that would support an alternative conclusion of law or finding of fact.

(15) "Public construction contract" means one of the various types of public construction contracts including, but not linited to, contracts with the government for the erection, construction, alteration, repair, or inprovement of any public structure, building, road, railway, or other improvement, and contracts with the governinent for the procurement of any other goods and services that are manufactured, designed, or produced in relation to the erection, construction, alteration, repair, or improvement of any structure, building, road, railway, or other improvenient. 
(16) "Tangible delay damages" means the additional costs, overhead expenses, and any other damages to the government that are reasonably likely to result from the completion of a public construction contract after the scheduled completion date; relative to intangible damages, the value of such damages may be conducive to prospective quantification by the government.

(17) "Writing" includes printing, typewriting, or any other intentional reduction to tangible form.

\section{§ 3. Provisions for Scheduled Completion Dates.}

(1) The government may include or cause to be included in public construction contracts a provision establishing the time within which all of the work or all of any specified portion of the work contemplated shall be completed. Except as stated in subsection (2), the schedule shall be based on the contracting officer's good-faith evaluation of the average actual time required for final completion on previous similar public construction contracts executed in any jurisdiction.

(2) Where the project contemplated is unique such that a perfunctory search fails to reveal similar public construction contracts undertaken in any jurisdiction, the contractor shall be allowed a reasonable period, based on any relevant industry standards available, to complete all of the work or all of any portion of the work contemplated.

\section{§ 4. Government Grace Period.}

(1) For a period of [two (2) years] after the effective date of this Act, the government may utilize standard form contracts and bid specifications that provide for liquidated delay damages without satisfying the procedural requirements of Sections 5,6 , and 7(1)-(3), provided said documents were drafted before the effective date of this Act. In such cases

(a) the remainder of this Act, including Section 7(4) and with the exception of Section 15, shall apply with full force and effect; and

(b) the government shall give notice, by addendum, to all solicitation recipients of the existence and relevance of this Act.

(2) If judicial review of the unconscionability of liquidated delay damages in a form contract is necessary during the [twoyear] period because of a dispute over the per diem amount of 
said damages, the following procedures and standards of review shall control in lieu of Section 15:

(a) the appropriate reviewing authority shall determine, as a matter of law, whether the liquidated delay dainages provision was procedurally unconscionable by reviewing the manner in which the contract was executed for compliance with the requirements of this Section and reasonable commercial standards of fair dealing;

(b) the reviewing authority shall determine, as a matter of law, whether the liquidated delay damages provision was substantively unconscionable by reviewing whether the per diem amount of such damages is fundamentally unfair considering the nature of the tangible and intangible damages that appeared likely at the time of contracting to result from delay; and

(c) the ultimate burden of persuasion shall remain at all times with the contractor.

\section{§ 5. Policy Regarding the Use of Liquidated Delay Damages.}

(1) The government may provide in public construction contracts that for each day completion is delayed beyond the scheduled completion date, the contractor shall forfeit and pay to the government a specified suin of money. Such liquidated delay damages provisions shall be used only when the time of delivery or performance is such an inportant factor in the award of the contract that the government or the public rationally may expect to suffer damage if the delivery or performance is delinquent. In deciding whether to include a liquidated delay damages provision in a contract, the contracting officer should consider the probable effect of the provision on such matters as pricing, competition, and the costs and difficulties of contract administration. The contracting officer should also consider the potential costs and difficulties of disbursing required bonus payments should the contractor complete the contract ahead of schedule.

(2) If a public construction contract provides for liquidated delay damages the contracting officer shall make a reasonable per diem estimate of any tangible delay damages that are reasonably likely to be suffered by the government or the public as a result of delay. The contracting officer also shall, if possible, articulate any plausible sources of intangible damage to the public from delay. The contracting officer shall document his findings regarding tangible and intangible damages. Such documentation constitutes 
the basis for the use of liquidated delay damages and shall be incorporated clearly and specifically into (i) the specifications upon which proposals or bids are received, and (ii) the contract.

(3) The per diem rate of liquidated delay damages used must be set in accordance with the schedules described in Section 6 in order to be protected by this Act. For each public construction procurement, both the per dien rate of liquidated delay damages and the entire relevant table of damages shall be incorporated clearly and specifically into (i) the specifications upon which proposals or bids are received, and (ii) the contract.

(4) The contracting officer shall take all reasonable steps to mitigate hquidated delay damages incurred by the contractor, which inay mclude termination and expedient rebidding of the contract. Efficient adıninistration of public construction contracts containing liquidated delay damages provisions is inperative to prevent undue loss to defaulting contractors and to protect the interests of the public.

\section{§ 6. Schedules of Liquidated Delay Damages.}

(1) The government shall establish a schedule of maximum per diem liquidated delay damages for each public construction contract category. The government shall update said schedules at least once every [two (2) years], but no more often than once [per year]. The schedules shall be based, at a minimum, on reasonable estimates of the maximum actual per diem delay damages experienced by the government and ineinbers of the public on contracts in each public construction procurement category over the [two preceding fiscal years], and the government shall document and make available to the public the bases of the estimates. Each schedule shall be divided into the following categories, relative to the original contract amounts:

[(a) $\$ 25,000$ and under;

(b) Over $\$ 25,000$ but less than $\$ 100,000$;

(c) $\$ 100,000$ or more but less than $\$ 250,000$;

(d) $\$ 250,000$ or more but less than $\$ 500,000$;

(e) $\$ 500,000$ or more but less than $\$ 2,500,000$;

(f) $\$ 2,500,000$ or more but less than $\$ 5,000,000$;

(g) $\$ 5,000,000$ or more but less than $\$ 10,000,000$;

(h) $\$ 10,000,000$ or more but less than $\$ 15,000,000$;

(i) $\$ 15,000,000$ or more but less than $\$ 20,000,000$; and

(j) $\$ 20,000,000$ and over.] 
(2) For each public construction contract executed by the government the relevant schedule shall be incorporated by reference into (i) the specifications upon which proposals or bids are received, and (ii) the contract.

\section{§ 7. Early Completion Bonuses.}

(1) If the government implements a provision for liquidated delay damages in a public construction contract, the contract also shall provide for an bonus payment payable to the contractor for early completion of the project. For purposes of this Section, the date of early completion is the date when all of the work or all of any specified portion of the work contemplated has been completed by the contractor. In accordance with Section 1 of this Act, the objective of said bonus payments shall be to encourage the contractor, through financial incentives, to work toward the timely completion of the public construction contract.

(2) The per diem amount of a bonus payment established under subsection (1) need not conform to the per diem amount of the liquidated delay damages fixed in the contract but shall not be less than [ 25 percent] of said damages.

(3) Bonus provisions, if used, shall be incorporated clearly and specifically into (i) the specifications upon which proposals or bids are received, and (ii) the contract.

(4) [Each state and the federal government] shall establish a fund from which bonus payments for early contract completions within the jurisdiction may be paid. Not less than [ 25 percent] of all damages paid by contractors to the government under provisions for hquidated delay damages shall be deposited to the credit of the [state/federal] bonus payment fund.

\section{§ 8. Apportionment of Delay.}

(1) Mutual responsibility for all or part of a delay in the completion of a public construction contract does not act as an absolute bar to recovery of liquidated delay damages by the government under any circumstances. In accordance with this mandate:

(a) subject to the exemption described in subsection (1)(b), every public construction contract executed after the effective date of this Act shall contain a provision authorizing the apportionment of responsibility for any delay between the govern- 
ment and the contractor. The provision also shall dictate that, except as provided in Section 12(2) and any other agreement between the parties, the contractor assumes responsibility for delays caused by circumstances unforeseen at the time of contracting. The purpose of said provision is to ensure that all parties are aware of the potential applicability of liquidated damages to project delays caused by unforeseen circumstances and to delays for which the contractor and the government are mutually responsible. In addition to its incorporation into the contract, the provision shall clearly be set fortli in the specifications upon which proposals or bids are received; and

(b) for a period of [two (2) years] after the effective date of this Act, the government may rely on standard form contracts and bid specifications without apportionment provisions provided said documents were drafted before the effective date of this Act. Under these circumstances, complete authorization for apportionment as provided in this Section shall be imputed to the parties.

(2) When a contracting officer determines that delay has occurred on a public construction contract and seeks to impose liquidated delay damages, he or she shall make a good-faith effort to apportion fault between the government and the contractor and may withhold payment in accordance with Section 9 only in relation to the percentage of delay attributable to the contractor. If the contracting officer is uncertain as to whether the contractor or the government is responsible for all or part of a delay, he or she shall refrain from withholding damages in respect to that part. The contracting officer shall issue his or her decisions in writing, and shall submit a copy of said writing to the contractor at or before the time that payment is withheld. The writing shall state clearly and specifically the reasons for the decisions reached, and shall inform the contractor of its rights and duties as provided in subsection (3).

(3) A contractor that is unsatisfied witl a contracting officer's decision in regard to apportionment may appeal the decision to the appropriate reviewing authority as provided in Section 14 or 15. The contracting officer is authorized to settle the dispute in accordance with the procedures described in Section 10 at any time, including the period after an appeal by the contractor has been imstituted. Pending final decision of an action, appeal, or final settlement, a contractor shall proceed diligently with performance of the contract. 


\section{§ 9. Government Withholding of Damages.}

If the contracting officer determines that the contractor has failed to complete a government construction contract by the scheduled coinpletion date, nothing in this Act shall prevent the government from withholding the appropriate and lawful amount of liquidated delay damages from progress payments or final payment otherwise due or to become due to the contractor; nor shall anything in this Act require the government to withhold said damages.

\section{§ 10. Government Remittal of Damages.}

(1) Once liquidated delay damages have been withheld from the contractor im accordance with Section 9, nothing in this Act shall prevent the government from remitting to the contractor all or a portion of the previously withheld damages as in its discretion may be just and equitable.

(2) Reasons for remitting previously withheld liquidated delay damages may include:

(a) expedited job progress by the contractor;

(b) evidence of increased effort on the part of the contractor, regardless of actual progress. Such evidence may include: (i) the employment of additional manpower at the project site, (ii) the application of additional equipment at the project site, or (iii) the use of alternative construction methods at the projects site; parties;

(c) resolving related or unrelated disputes between the

(d) providing consideration for work in addition to that required by the original contract; and

(e) any other reason that will demonstrate the government's good faith in contemplating liquidated delay damages.

\section{\$ 11. Abandonment by Contractor.}

(1) Abandonment of a public construction contract by the contractor either before of after the scheduled completion date does not act as an absolute bar to recovery of liquidated delay damages by the government, nor does the act of abandonment invalidate liquidated delay damages previously withheld by the government. In accordance with these mandates: 
(a) subject to the exemption described in subsection (1)(b), every public construction contract executed after the effective date of this Act shall contain a provision authorizing the imposition of liquidated delay damages even when abandonment occurs. The provision also shall clearly be set forth in the specifications upon which proposals or bids are received. The purpose of said provision is to ensure that all parties are aware of the applicability of liquidated delay damages notwithstanding abandonment by the contractor; and

(b) for a period of [two (2) years] after the effective date of this Act, the government may rely on standard form contracts and bid specifications without abandonment provisions provided said documents were drafted before the effective date of this Act. Under these circumstances, complete authorization for the imposition of liquidated delay damages as provided in this Section shall be imputed to the parties.

(2) When a contractor abandons performance of a public construction contract, the contracting officer shall determine in good faith the precise date of the abandonment. If the contractor has expressly communicated its intent to abandon the contract, the date of abandonment shall be the date on which the contracting officer received such communication. If the contractor has not expressly communicated its intent to abandon, the contracting officer may consider abandonment to have occurred on

(a) the date on which the contractor or its agents ceased activity at the job site;

(b) the date on which the contractor finished removing its equipment from the job site; or

(c) any other date on which the contracting officer reasonably could conclude, based on acts committed by the contractor or its agents, that the contractor had abandoned.

(3) If the date of abandonment as determined in subsection (2) falls after the scheduled completion date of the contract, the government shall be entitled to withhold per diem liquidated delay damages in accordance with the procedures specified in Sections 8 and 9 of this Act for each day between the scheduled completion date and the date of abandonment. The contracting officer shall issue his or her decisions in writing, and shall submit a copy of said writing to the contractor at or before the time that payment is withheld. The writing shall state the reasons for the decisions 
reached, and shall inform the contractor of its rights as provided in Sections 14 and 15.

(4) If the contractor abandons performance of a public construction contract after the scheduled completion date and the government believes that the contractor is responsible for any delay after the date of abandonment, the government may not assess liquidated delay damages in addition to those permitted by subsection (3) without petitioning the appropriate reviewing authority to determine the period against which liquidated delay damages lawfully may be applied. If such a determination is sought by the government, the reviewing authority is authorized to apportion responsibility for delay after the date of abandonment through a trial de novo. Following the presentation of evidence the reviewing authority shall direct the trier of fact to find separate special verdicts determining the percentage of delay attributable to each party, measured in full day increments.

(5) If the contractor abandons performance of a public construction contract before the scheduled completion date and the government believes that the contractor is responsible for any subsequent delay in the completion of the contract, the governinent may not assess liquidated delay damages against the contractor without petitioning the appropriate reviewing authority to determine the period against which liquidated delay damages lawfully may be applied. If such a determination is sought by the government, the reviewing authority is authorized to apportion responsibility for delay through a trial de novo. Following the presentation of evidence the reviewing authority shall direct the trier of fact to find separate special verdicts determining the percentage of delay attributable to each party, measured in full day increnients.

(6) Once the finder of fact has found special verdicts as provided in subsection (4) or subsection (5), the reviewing authority may

(a) order the government to remit or withhold additional payment in amounts consistent with the special verdicts and the contractual per dien amount of liquidated delay damages; or

(b) enter judgment against the contractor in an amount consistent with the special verdicts and the contractual per diem amount of liquidated delay damages. 


\section{§ 12. Final Completion.}

(1) Subject to the other restrictions imposed by this Act, the government shall be entitled to withhold the per diem amount of liquidated delay damages in accordance witl the procedures specified in Sections 8 and 9 for eacli day between the scheduled completion date and the date of final completion, which is the date when all of the work or all of any specified portion of the work contemplated shall be completed. Therefore, except as provided in subsection (2), the government's entitlement to withhold liquidated delay damages sliall not toll on the date of substantial completion or any other date unless the contract clearly and explicitly so provides, at the discretion of the government.

(2) Once the contractor lias reached the cleanup stage on a delayed public construction contract, the government shall not assess liquidated delay damages if circumstances unforeseen at the time of contracting prevent immediate progress to final completion by the contractor. The government may, however, withhold final payinent. If it subsequently is practicable for the contractor to progress expediently to final completion, but the contractor fails to do so, the government may assess additional liquidated delay damages as appropriate.

\section{§ 13. Waiver of Government Rights.}

No waiver of the scheduled completion date of a public construction contract or of the government's right to claim liquidated delay damages thereafter shall be effective unless the waiver is granted to the contractor in writing and is signed by the contracting officer. It sliall be the responsibility of the contractor, therefore, to demand said writing from the government if the contractor believes waiver has occurred.

\section{\$14. Judicial Review of the Period of Delay.}

(1) If judicial review of the assessment of liquidated delay damages is necessary because of a dispute over the period of time that the contracting officer has determined represents the total delay on the contract, the appropriate reviewing authority is authorized, on petition by the contractor, to conduct a hearing or special proceeding to settle the disputed issues. During said liearing 
or special proceeding, the following procedures and standards of review shall control:

(a) in cases where the contractor has abandoned performance, the reviewing authority shall affirm the findings of the contracting officer regarding the date of abandonment if the contracting officer had a rational basis to conclude that abandonment of the contract actually occurred on that date based on a review of the contracting officer's records in support of his or her findings and any contrary information provided by the contractor. If the contracting officer did not have a rational basis, the reviewing authority shall determine as a matter of law the appropriate date of abandonment;

(b) in cases where the governinent is alleged to have waived either the scheduled completion date or its right to liquidated delay damages after the scheduled completion date, the reviewing authority shall find as a matter of law that such waiver has occurred only in accordance with Section 13;

(c) in cases where the government is alleged to have assessed liquidated delay damages after the date of final completion of the project, the reviewing authority shall affirm the findings of the contracting officer regarding the date of final completion if said findings are supported by substantial evidence based on a review of the contracting officer's documentation in support of his or her findings and any contrary information provided by the contractor. If the contracting officer's findings are not supported by substantial evidence, the reviewing authority shall determine as a matter of law the appropriate date of final completion;

(d) in cases where the government is alleged to have failed to mitigate liquidated delay damages in accordance with Section 5(4), the reviewing authority shall determine as a matter of law the period of the alleged failure based on information provided by the parties. The contractor shall not be responsible for any period of delay that the governinent reasonably should have avoided.

(2) Once the reviewing authority has made conclusions of law as provided in subsection (1), the reviewing authority may

(a) order the government to remit or withhold additional payment in amounts consistent with the conclusions of law and/or the special verdicts; or

(b) enter judgment against the contractor in an amount consistent with the conclusions of law and/or the special verdicts. 
(3) If judicial review of the assessment of liquidated damages is necessary because of a dispute over proportion of the total delay for which the contractor is responsible, the reviewing authority is authorized, on petition by the contractor, to apportion responsibility for the delay through a trial de novo. Following the presentation of evidence the reviewing authority shall direct the trier of fact to find separate special verdicts determining the percentage of delay attributable to each party, measured in full day increments.

(4) Once the finder of fact has found special verdicts as provided in subsection (3), the reviewing authority shall compare the percentage of the total delay attributed to the contractor by the verdicts with the percentage attributed to the contractor by the contracting officer. If the percentage fixed by the verdicts is more than [ten (10)] percentage points less than the percentage fixed by the contracting officer, the contractor is the prevailing party and the reviewing authority shall order the government to remit additional payment in amounts consistent with the verdicts. If the percentage fixed by the verdicts is equal to or fewer than [ten (10)] percentage points less, or is greater than, the percentage fixed by the contracting officer, the government is the prevailing party and the reviewing authority may enter judgment against the contractor in an amount consistent with the verdicts.

(5) In addition to the relief granted in accordance with subsection (4), if the reviewing authority has undertaken a trial de novo as provided in subsection (3) it shall enter judgment in favor of the prevailing party for costs and reasonable attorneys' fees.

\section{\$15. Judicial Review of the Unconscionability of Liquidated Delay Damages.}

(1) If judicial review of the assessment of liquidated delay damages is necessary because of a dispute over the per diem amount of such damages, the appropriate reviewing authority is authorized, on petition by the contractor, to conduct a hearing or special proceeding to settle the dispute. During said hearing or special proceeding, the following procedures and standards of review shall control:

(a) the reviewing authority shall determine, as a matter of law, whether the liquidated delay damages provision was procedurally unconscionable by reviewing the manner in which the contract was executed as provided in subsection (2); 
(b) the reviewing authority shall determine, as a matter of law, whether the liquidated delay damages provision was substantively unconscionable by reviewing the manner in which the per diem anount of damages was established as provided in subsection (2); and

(c) the ultimate burden of persuasion shall remain, at all times, with the contractor.

(2) A determination of unconscionability shall be based upon findings of fact; such findings of fact depend on a comparative appraisal of all of the components in the case. Liquidated delay damages whose per diem rate is within the limit inposed by the relevant government schedule of liquidated delay damages, however, shall be presumed procedurally and substantively conscionable and enforceable according to their terms, subject to the following considerations:

(a) whether the government table of liquidated delay damages was established in accordance with Section 6; failure by the government to follow the appropriate procedure in establishing the table represents significant indicia of substantive unconscionability;

(b) whether the scheduled coinpletion date was established in accordance with Section 3; failure by the government to follow the appropriate procedure in estabhishing the date represents significant indicia of substantive unconscionability;

(c) whether the government has satisfied the notice requirements of Section 5 regarding the inclusion in solicitation materials and the contract of an estimate of tangible danages that reasonably could have been expected, at the time of contracting, to result from delay; failure by the government to estimate tangible damages represents extremely significant indicia of substantive unconscionability in the absence of any clain by the government for intangible damages; when intangible damages have been claimed, such failure represents negligible to extremely significant indicia of substantive unconscionability depending on the nature and/or magnitude of the intangible damages articulated; whether the government suffered actual delay damages shall be irrelevant in the determination of unconscionability;

(d) whether the government has satisfied the notice requirements of Section 5 regarding the inclusion in solicitation materials and the contract of any plausible source of intangible dainage to the public that could result from delay; if the govern- 
ment has articulated such a source, the reviewing authority shall presume that at least a nominal amount of such damages has occurred but shall be receptive to evidence from the parties regarding the actual amount; failure by the government to articulate a source of intangible dainages represents extremely significant indicia of substantive unconscionability in the absence of any claim by the government for tangible dainages; when tangible damages have been clained, such failure represents negligible to extremely significant indicia of substantive unconscionabihity depending on the magnitude of the tangible damages estinated;

(e) whether the government has satisfied the notice requirements of Section 5 regarding the inclusion in solicitation materials and the contract of all other required information; failure by the government to meet such requirements represents negligible to extremely significant indicia of procedural unconscionability depending on the magnitude of the failure;

(f) whether the government has satisfied the notice requirements of this Act regarding advance coinmunication to the contractor of contracting officer decisions; failure by the government to meet such requirements also represents negligible to extremely significant indicia of procedural unconscionability depending on the magnitude of the failure; and

(g) whether either party has acted in bad faith in its deahings with the other; bad faith by the government shall lead to a presumption that the liquidated delay damages are procedurally and substantively unconscionable; in the absence of bad faith by the government, bad faith by the contractor conversely shall lead to a presumption that the liquidated delay damages imposed are conscionable.

(3) Liquidated delay damages whose per diem amount is fixed in excess of the limit imposed by the relevant government schedule of liquidated delay damages shall lead to a presunption that the damages are substantively unconscionable.

(4) The parties shall be afforded a reasonable opportunity to present evidence to aid the reviewing authority in determining whether a hquidated delay damages provision is procedurally or substantively unconscionable.

(5) If the reviewing authority as a matter of law finds the liquidated delay damages provision to have been both procedurally and substantively unconscionable at the time it was made the authority may refuse to enforce the provision; the authority there- 
upon is authorized, on petition by the government, to determine the contractor's liability for actual delay damages through a trial de novo.

(6) Review of a determination of conscionability or unconscionability is limited to determining whetler the fimdings of fact are supported by substantial evidence, and if so, whether the findings support the conclusion of law. 